\title{
Striking Back against Fungal Infections: The Utilization of Nanosystems for Antifungal Strategies
}

\author{
Wei Du ${ }^{1}$, Yiru Gao ${ }^{1}$, Li Liu ${ }^{1}$, Sixiang Sai ${ }^{2, *}$ and Chen Ding ${ }^{1, *(\mathbb{D}}$ \\ 1 College of Life and Health Sciences, Northeastern University, Shenyang 110015, China; \\ 1710064@stu.neu.edu.cn (W.D.); 1910449@stu.neu.edu.cn (Y.G.); 1901376@stu.neu.edu.cn (L.L.) \\ 2 School of Medicine, Binzhou Medical University, Yantai 264003, China \\ * Correspondence: sixiang.sai@bzmc.edu.cn (S.S.); dingchen@mail.neu.edu.cn (C.D.)
}

check for updates

Citation: Du, W.; Gao, Y.; Liu, L.; Sai, S.; Ding, C. Striking Back against Fungal Infections: The Utilization of Nanosystems for Antifungal Strategies. Int. J. Mol. Sci. 2021, 22, 10104. https://doi.org/10.3390/ ijms221810104

Academic Editors:

Stefano Giovagnoli

and Alessandro Di Michele

Received: 19 July 2021

Accepted: 15 September 2021

Published: 18 September 2021

Publisher's Note: MDPI stays neutral with regard to jurisdictional claims in published maps and institutional affiliations.

Copyright: (c) 2021 by the authors. Licensee MDPI, Basel, Switzerland. This article is an open access article distributed under the terms and conditions of the Creative Commons Attribution (CC BY) license (https:// creativecommons.org/licenses/by/ $4.0 /)$.
Abstract: Fungal infections have become a major health concern, given that invasive infections by Candida, Cryptococcus, and Aspergillus species have led to millions of mortalities. Conventional antifungal drugs including polyenes, echinocandins, azoles, allylamins, and antimetabolites have been used for decades, but their limitations include off-target toxicity, drug-resistance, poor water solubility, low bioavailability, and weak tissue penetration, which cannot be ignored. These drawbacks have led to the emergence of novel antifungal therapies. In this review, we discuss the nanosystems that are currently utilized for drug delivery and the application of antifungal therapies.

Keywords: fungal infection; antifungal therapies; nanosystems

\section{Fungal Infection}

Fungal infections are a major threat to humans and number in the billions, leading to more than 1.5 million deaths annually [1-3]. Candida, Aspergillus, and Cryptococcus, are the major pathogenic fungi in humans, causing $90 \%$ of the deaths in both immunocompetent and immunocompromised individuals [2,3]. Other pathogenic fungi, including Pneumocystis, Coccidioides, and Histoplasma, can also cause severe tissue damage and even death (Table 1).

The type of fungal infection is highly dependent on the fungal species and the immune status of the hosts [4]. For instance, superficial infections in humans are among the most common fungal infections, occurring in over 1 billion people. Over 135 million women are diagnosed with Candida mucosal infections [5]. However, the most devastating fungal infections are invasive. These are initiated by the inhalation or inoculation of fungal spores or by an imbalance of the commensal fungi of the host. Invasive candidiasis, aspergillosis, and cryptococcosis occur in the bloodstream and deep-seated organs as a result of fungi from the genera Candida, Aspergillus, and Cryptococcus, respectively. Additionally, fungal infection also results in or enhances severe host allergic responses, including asthma, cystic fibrosis, or chronic nasal sinus symptoms [6-10].

Candida spp. make up the commensal fungi residing within human superficial, mucosal, or intestinal tract regions, and their colonization and growth are highly restricted when the host is immunocompetent. Studies demonstrate that over 15 distinct Candida species are pathogenic fungi, of which five species cause the most invasive infections in humans: Candida albicans, Candida krusei, Candida glabrat, Candida tropicalis, and Candida parapsilosis [11-14]. Recent studies show that Candida auris has emerged globally as a multidrug-resistant fungal pathogen that leads to significant patient mortality [15-18]. In addition to Candida, Cryptococcus, and Aspergillus lead to severe lung infections and can lead to fatal infections, including pneumonia and meningocephalitis. 
Table 1. Pathogenic fungi caused human diseases.

\begin{tabular}{|c|c|c|c|}
\hline Diseases & Fungal Species & Conventional Treatments & Common Clinical Features and Symptoms \\
\hline \multirow{6}{*}{ Dimorphic mycoses } & B. dermatitidis & \multirow{6}{*}{ Azoles and polyenes } & $\begin{array}{l}\text { Cutaneous disease } \\
\text { Pulmonary disease } \\
\text { Disseminated disease }\end{array}$ \\
\hline & C. immitis & & Fever, cough, shortness of breath, chest pains \\
\hline & C. posadasii & & Lung cavities (commonly occurs in children) \\
\hline & H. capsulatum & & $\begin{array}{l}\text { Acute pulmonary histoplasmosis } \\
\text { Chronic pulmonary histoplasmosis } \\
\text { Disseminated histoplasmosis } \\
\text { Histoplasmoma } \\
\text { African histoplasmosis }\end{array}$ \\
\hline & P. brasiliensis & & Systemic mycosis, paracoccidioidomycosis \\
\hline & T. marneffei & & $\begin{array}{l}\text { Common symptoms include fever, malaise, } \\
\text { weight loss, skin and soft tissue lesions, } \\
\text { hepatosplenomegaly, lymphadenopathy, } \\
\text { cough and dyspnea } \\
\text { Less common symptoms include } \\
\text { osteoarticular involvement, abdominal pain } \\
\text { and diarrhea [19] }\end{array}$ \\
\hline \multirow{2}{*}{ Disseminated cryptococcosis } & C. neoformans & \multirow{2}{*}{$\begin{array}{l}\text { Azoles, polyenes } \\
\text { and antimetabolites }\end{array}$} & \multirow{2}{*}{$\begin{array}{l}\text { Cryptococcal meningocephalitis } \\
\text { Cryptococcal pneumonia }\end{array}$} \\
\hline & C. gattii & & \\
\hline \multirow{6}{*}{ Aspergillosis } & A. fumigatus & \multirow{6}{*}{ Azoles, polyenes, echinocandins } & \multirow{6}{*}{$\begin{array}{l}\text { Chronic cavitary tuberculosis } \\
\text { Mild, self-limited hemoptysis } \\
\text { Chronic necrotizing pulmonary aspergillosis } \\
\text { Chronic fibrotic pulmonary aspergillosis } \\
\text { Severe asthma } \\
\text { Allergic bronchopulmonary aspergillosis (in } \\
\text { atopic patients) [20] }\end{array}$} \\
\hline & A. flavus & & \\
\hline & A. terreus & & \\
\hline & A. nidulans & & \\
\hline & A. niger & & \\
\hline & A. clavatus & & \\
\hline \multirow{6}{*}{ Candidiasis } & C. albicans & \multirow{6}{*}{ Azoles, polyenes, echinocandins } & \multirow{6}{*}{$\begin{array}{l}\text { Mucosal Candida infection, including } \\
\text { oropharynx, esophagus and vagina } \\
\text { Candidemia } \\
\text { Acute disseminated candidiasis } \\
\text { Infective endocarditis } \\
\text { Vertebral osteomyelitis and diskitis } \\
\text { Endophthalmitis } \\
\text { Meningitis } \\
\text { Septic arthritis } \\
\text { Tenosynovitis }[11,21]\end{array}$} \\
\hline & C. tropicalis & & \\
\hline & C. glabrata & & \\
\hline & C. parapsilosis & & \\
\hline & C. krusei & & \\
\hline & C. auris & & \\
\hline \multirow{3}{*}{ Mucormycosis } & Rhizopus spp. & \multirow{3}{*}{ Polyenes and azoles } & \multirow{3}{*}{$\begin{array}{l}\text { Tissue necrosis } \\
\text { Sinus pain, nasal congestion, fever, soft tissue } \\
\text { swelling and headache } \\
\text { Blurred vision or loss of vision } \\
\text { Cranial neuropathies or cerebral abscesses } \\
\text { Cutaneous mucormycosis, skin swelling, } \\
\text { necrosis and formation of abscesses [22] }\end{array}$} \\
\hline & Mucor spp. & & \\
\hline & Cunninghamella bertholletiae & & \\
\hline
\end{tabular}

As with candidiasis, cryptococcosis is also a globally distributed invasive fungal infection caused by Cryptococcus species and leads to significant mortality and therapeutic challenges. Cryptococcus was first identified in 1894 from the tibia of a 31-year-old woman, and cryptococcosis has been attributed to a single fungal species Cryptococcus neoformans. The cryptococcosis epidemic is highly consistent with the AIDS pandemic of the 1980s [23-27]. However, because molecular technology and epidemic research have improved, C. neoformans var. gattii was classified as a distinct species, C. gattii, in 2002. This species has been considered the causative fungi for the outbreak of cryptococcosis in the North American Pacific Northwest in 1999 [28-36].

Ecologically, cryptococci reside in various tree species, especially the waxier cuticles, while $C$. neoformans is particularly abundant in pigeon excreta [25,37]. These two cryptococci can also survive and replicate in soil, amoebae, and vertebrates [38]. Furthermore, 
they have developed sophisticated strategies, such as thermo-tolerance, $\mathrm{pH}$-tolerance, and resistance to phagocytosis from host immune cells, which facilitate fungal growth and persistence within environmental niches and vertebrates [39-43]. These strategies endow cryptococci with growth advantages, including severe virulence. Cryptococcal infection begins with the inhalation of cryptococci spores into the lungs and can cause pneumonia in immunosuppressed patients. However, these fungal cells establish an asymptomatic latent infection in immunocompetent hosts, where the colonizing fungal cells can disseminate to other tissues, especially the central nervous system, which occurs through uncharacterized mechanisms [44,45]. Once the brain has been colonized, cryptococcosis leads to a devastating infection of the meninges and lethal meningoencephalitis [46].

Aspergillus is a saprophytic fungus found in soil and comprises at least 200 species. Aspergillus spp. is common and isolated from cultures of the respiratory tracts of asymptomatic patients who lack evidence of invasive or allergic disease [47-49]. Moreover, aspergillosis is highly associated with chronic obstructive pulmonary disease [50]. Aspergillus spp. is much more common than other fungi, and approximately $37 \%$ of healthy adults carry these fungi [51]. However, they are not always associated with infection. Nevertheless, colonization by Aspergillus spp. is associated with increased risk of invasive infections across a wide range of immunocompromised individuals [52]. To date, Aspergillus pathogens include A. fumigatus, A. flavus, A. niger, A. terrus, A. clavatus, and A. nidulans, the first of which is the most common.

Distinct from Cryptococcus, however, Aspergillus can produce small asexual spores, called conidia, which are 2-3 $\mu \mathrm{m}$ in diameter. The dispersal of $A$. fumigatus produces conidia that are hydrophobic and can spread and sustain for a much longer time in the air, making it a highly virulent fungus [53-55]. In healthy individuals, epithelial cells in the airway and alveolar macrophages efficiently eliminate inhaled conidia, but resident conidia can evade mucocilliary clearance and lodge in the alveoli deep in the lungs, germinating into short hyphae in less than $6 \mathrm{~h}$ [56]. Aside from host immune status, Aspergillus colonization is related to certain genetic factors of the host. Impaired expression of the transcriptional factor ZNF77 in bronchial epithelia can result in the destruction of epithelial cell integrity, and upregulation of extracellular matrix proteins has been shown to facilitate conidial adhesion [57].

\section{Conventional Treatments for Candidiasis, Cryptococcosis, and Aspergillosis}

Researchers have developed several antifungal treatments to contend with the increasing challenge of fungal infections. However, the significant side effects and development of drug resistance in fungi have not been adequately addressed [58-61].

All fungal cells produce cell walls that are based on aminopolysaccharide structures and referred to as the chitin layer. This layer has slight differences between yeasts and filamentous cells, which contain matrices of $\beta-1,3$-glucans plus either $\beta-1,6$-glucans or $\alpha-1,3$-glucans, respectively [62-65].

In addition, yeast cells construct galactosaminoglycans and protein-based outer layers, and galactomannan is an additional element in the final layer of filamentous cells. Moreover, fungal cells utilize ergosterol rather than cholesterol to manufacture cell membranes [66,67]. These elements of fungal cell walls and membranes distinguish invasive fungi from host mammalian cells and act as therapeutic targets for antifungal drugs (Figure 1).

Common clinical antifungal drugs have distinct molecular targets and can be divided into 5 categories (Figure 1, Table 2): (i) azoles, (ii) polyenes, (iii) echinocandins, (iv) allylamines, and (v) antimetabolites. Azoles are chemically synthesized small molecules that primarily block the ergosterol synthesis pathway by inhibiting lanosterol $14 \alpha$-demethylase (Erg11), which is essential for fungal cell membrane formation. They have been used as antifungal drugs since the 1970s, when they were found to impart a broad spectrum of activity against various fungal species. 


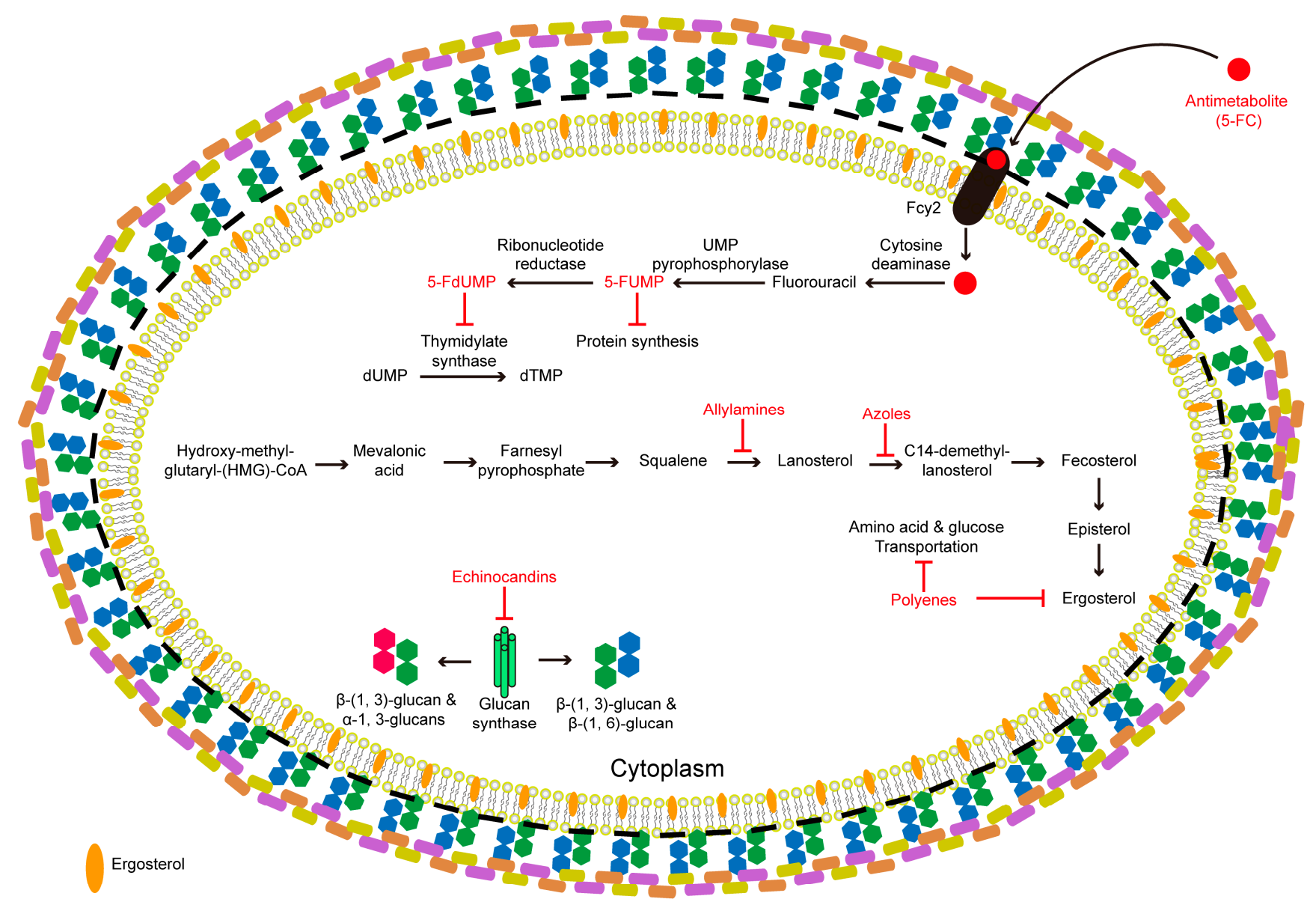

Mannoprotein

Figure 1. Schematic representation of the conventional antifungal agents, their targets, and actions. Antimetabolite, 5-Fluorocytosine (5-FC), is a fluorinated pyrimidine analog with fungicidal activity via interfering the pyrimidine metabolism, RNA/DNA and protein synthesis. First, 5-FC is taken up by fungal cells via a cytosine permease (encoded by gene FCY2) and is converted to 5-fluorouracil (5-FU), and is then transformed by UMP pyrophosphorylase into 5-fluorourdine monophosphate (5-FUMP). Then, 5-FUMP is incorporated into RNAs to inhibit the protein synthesis. Additionally, ribonucleotide reductase enables the conversion of 5-FUMP into 5-fluorodeoxyuridine monophosphate (5-FdUMP), a potent inhibitor of thymidylate synthase that inhibits fungal DNA synthesis and nuclear division. Azoles are inhibitors for cytochrome P450-dependent enzyme lanosterol 14 $\alpha$-demethylase (CYP51) encoded by the ERG11 gene, and thus block the conversion of lanosterol to ergosterol. Allylamines block ergosterol biosynthesis via inhibiting squalene epoxidase (ERG1) that lead to squalene accumulation and increased permeability may cause the disruption of cellular organization. Echinocandins act as noncompetitive inhibitors of $\beta-(1,3)$-D-glucan synthase enzyme complex and leads to disruption of the cell wall structure, resulting in osmotic instability and fungal cell death. Polyenes specifically bind to the lipid bilayer and form a complex with the ergosterol producing pores that leads to the disruption of the cell membrane, leakage of the cytoplasmic, contents and oxidative damage in fungal cells. Amphotericin B (AmB) binds ergosterol and forms an extra-membranous fungicidal sterol sponge destabilizing membrane function. 
Table 2. Conventional anti-fungal therapies.

\begin{tabular}{|c|c|c|c|c|c|}
\hline Antifungal Agents & Drugs & Targets & Mechanisms & Administration Routes & Side Effects \\
\hline \multirow{8}{*}{ Azoles } & Econazole (ECO) & $\begin{array}{l}\text { Epidermophyton, } \\
\text { Microsporum, Trichophyton }\end{array}$ & \multirow{8}{*}{$\begin{array}{l}\text { Inhibits the fungal cytochrome } \\
\text { P450-dependnent enzyme } \\
14 \alpha \text {-lanosterol demethylase } \\
\text { encoded by the ERG11 gene that } \\
\text { converts lanosterol to ergosterol } \\
\text { in the fungal cell membrane; } \\
\text { thus, inhibits fungal growth and } \\
\text { replication }[68,69]\end{array}$} & Topical & \multirow{2}{*}{$\begin{array}{l}\text { Well tolerated, but rare cases } \\
\text { with local irritation, itching, and } \\
\text { burning [70] }\end{array}$} \\
\hline & Sertaconazole (SER) & Epidermophyton, Trichophyton & & & \\
\hline & Miconazole (MCZ) & $\begin{array}{l}\text { Candida spp., Aspergillus spp., } \\
\text { Cryptococcus neoformans, } \\
\text { Histoplasma capsulatum, } \\
\text { Pseudallescheria boydii, } \\
\text { Trichosporon }\end{array}$ & & $\begin{array}{l}\text { Topical } \\
\text { Intravenous }\end{array}$ & $\begin{array}{l}\text { May cause congenital disease } \\
\text { when combined with } \\
\text { metronidazole during pregnancy }\end{array}$ \\
\hline & Sulconazole (SUL) & $\begin{array}{l}\text { Epidermophyton, Microsporum, } \\
\text { Trichophyton, } \\
\text { Candida spp. }\end{array}$ & & Topical & $\begin{array}{l}\text { Redness, irritation, contact } \\
\text { dermatitis, and pruritus [71] }\end{array}$ \\
\hline & Tioconazole (TIO) & Candida spp. & & Topical & $\begin{array}{l}\text { Itching, discomfort, rash, } \\
\text { erythema, mild burning, } \\
\text { and stinging } \\
\text { May cause severe local adverse } \\
\text { effects [72] }\end{array}$ \\
\hline & Clotrimazole (CLT) & $\begin{array}{l}\text { Candida spp., Epidermophyton, } \\
\text { Microsporum, Trichophyton }\end{array}$ & & $\begin{array}{l}\text { Topical } \\
\text { Oral }\end{array}$ & $\begin{array}{l}\text { Gastrointestinal tract toxicity as } \\
\text { consumption with oral lozenges } \\
\text { Elevation of liver enzymes [76] }\end{array}$ \\
\hline & Luliconazole (LUL) & Epidermophyton, Trichophyton & & Topical & No significant side effects \\
\hline & Itraconazole (ITC) & $\begin{array}{l}\text { Aspergillus spp., Blastomyces, } \\
\text { Histoplasma capsulatum }\end{array}$ & & $\begin{array}{l}\text { Systemic application } \\
\text { Topical } \\
\text { Parenteral }\end{array}$ & $\begin{array}{l}\text { Diarrhea } \\
\text { Abdominal pain } \\
\text { Hypertriglyceridemia } \\
\text { Pancreatitis } \\
\text { Liver injury } \\
\text { Cardia dysrhythmia }\end{array}$ \\
\hline
\end{tabular}


Table 2. Cont.

\begin{tabular}{|c|c|c|c|c|c|}
\hline Antifungal Agents & Drugs & Targets & Mechanisms & Administration Routes & Side Effects \\
\hline & Posaconazole (POS) & Aspergillus spp., Candida spp. & & Systemic application & $\begin{array}{l}\text { Fever, diarrhea, nausea, } \\
\text { vomiting, headache } \\
\text { Hypokalemia, rash } \\
\text { Thrombocytopenia, } \\
\text { abdominal pain } \\
\text { Peripheral neuropathies } \\
\text { Hepatocellular damage }\end{array}$ \\
\hline & Fluconazole (FLC) & $\begin{array}{l}\text { Candida spp., } \\
\text { Cryptococcus spp. }\end{array}$ & & $\begin{array}{l}\text { Systemic application } \\
\text { Topical } \\
\text { Oral } \\
\text { Parenteral }\end{array}$ & $\begin{array}{l}\text { Liver dysfunction }[77,78] \\
\text { Anaphylaxis }\end{array}$ \\
\hline & Voriconazole (VRC) & $\begin{array}{l}\text { Aspergillus spp., } \\
\text { Candida spp., } \\
\text { Fusarium spp., } \\
\text { Scedosporium spp. }\end{array}$ & & Systemic application & $\begin{array}{l}\text { Peripheral neuropathies } \\
\text { Pancreatitis } \\
\text { Periostitis }[79,80] \\
\text { Phototoxic reactions } \\
\text { Squamous cell carcinoma }\end{array}$ \\
\hline & Efinaconazole (EFI) & Trichophyton & & Topical & $\begin{array}{l}\text { No significant toxicity reported, } \\
\text { but causes embryotoxicity in } \\
\text { animal model [81] }\end{array}$ \\
\hline & Isavuconazonium (ISA) & Aspergillus spp., Mucor spp. & & Systemic application & $\begin{array}{l}\text { Headache, nausea, vomiting, } \\
\text { diarrhea, elevated liver } \\
\text { enzymes [82] }\end{array}$ \\
\hline \multirow[t]{2}{*}{ Polyenes } & Amphotericin B (AmB) & $\begin{array}{l}\text { Aspergillus spp., Candida spp., } \\
\text { Cryptococcus spp. }\end{array}$ & \multirow{2}{*}{$\begin{array}{l}\text { Directly interacts with cell } \\
\text { membrane component and } \\
\text { ergosterol, induces the formation } \\
\text { of pores, and alters the cell } \\
\text { permeability, causing the effusion } \\
\text { of cytoplasmic content and } \\
\text { fungicidal consequences }\end{array}$} & $\begin{array}{l}\text { Systemic application } \\
\text { Topical }\end{array}$ & $\begin{array}{l}\text { Renal failure, electrolyte } \\
\text { imbalance, and hepatotoxicity } \\
\text { Fever, chills, headache, myalgias, } \\
\text { bone marrow, and kidney toxicity }\end{array}$ \\
\hline & Nystatin B (NYT) & Candida spp. & & Oral & $\begin{array}{l}\text { Mild gastrointestinal symptoms, } \\
\text { acute renal failure [83] }\end{array}$ \\
\hline
\end{tabular}


Table 2. Cont

\begin{tabular}{|c|c|c|c|c|c|}
\hline Antifungal Agents & Drugs & Targets & Mechanisms & Administration Routes & Side Effects \\
\hline & Natamycin (NAT) & $\begin{array}{l}\text { Fusarium spp., } \\
\text { Aspergillus spp. [84] }\end{array}$ & $\begin{array}{l}\text { Inhibits the amino acid and } \\
\text { glucose transportation, leads to } \\
\text { ergosterol-specific and reversible } \\
\text { inhibition of membrane transport } \\
\text { proteins without altering the cell } \\
\text { membrane permeability [85] }\end{array}$ & Topical & $\begin{array}{l}\text { No severe side effects have } \\
\text { been reported } \\
\text { Rare cases reported mild } \\
\text { irritation, redness, foreign body } \\
\text { sensation, stinging, burning } \\
\text { sensation, and tearing [86] }\end{array}$ \\
\hline \multirow{3}{*}{ Echinocandins } & Anidulafungin (AFG) & Candida spp. $[87,88]$ & \multirow{3}{*}{$\begin{array}{l}\text { Acts as the noncompetitive } \\
\text { inhibitor of } \beta-1,3 \text {-D-glucan } \\
\text { synthase, which leads to the } \\
\text { inhibition of the synthesis of } \\
\text { glucan. Thus, it compromises } \\
\text { the fungal cell wall stability } \\
\text { and synthesis. }\end{array}$} & Intravenous & $\begin{array}{l}\text { No severe side effects have } \\
\text { been reported }\end{array}$ \\
\hline & Caspofungin (CFG) & Candida spp., Aspergillus spp. & & Intravenous & $\begin{array}{l}\text { No severe side effects have } \\
\text { been reported } \\
\text { Rare cases of chills, fever, } \\
\text { phlebitis/thrombophlebitis, } \\
\text { tachycardia, nausea, vomiting, } \\
\text { rash, abdominal pain, headache, } \\
\text { and diarrhea [89] }\end{array}$ \\
\hline & Micafungin (MFG) & Candida spp. & & Intravenous & $\begin{array}{l}\text { Risk of hepatocarcinogenesis } \\
\text { Rare cases of vomiting, nausea, } \\
\text { diarrhea }[89,90]\end{array}$ \\
\hline \multirow[b]{2}{*}{ Allylamins } & Butenafine (BUT) & $\begin{array}{l}\text { Epidermophyton, Microsporum, } \\
\text { Trichophyton } \\
\text { Aspergillus spp. }\end{array}$ & \multirow[b]{2}{*}{$\begin{array}{l}\text { Acts as the squalene epoxidase } \\
\text { inhibitor that inhibits the } \\
\text { ergosterol synthesis and causes } \\
\text { the fungal cell lysis via altering } \\
\text { cell membrane permeability }\end{array}$} & Topical & $\begin{array}{l}\text { Mild burning and/or stinging } \\
\text { are common [91] }\end{array}$ \\
\hline & Terbinafine (TRB) & Trichophyton & & Topical & $\begin{array}{l}\text { Headache } \\
\text { Gastrointestinal symptoms } \\
\text { Severe neutropenia } \\
\text { Thrombocytopenia } \\
\text { Liver failure or injury } \\
\text { Taste, visual, and smell } \\
\text { disturbances } \\
\text { Depressive symptoms }[92,93]\end{array}$ \\
\hline
\end{tabular}


Table 2. Cont.

\begin{tabular}{|c|c|c|c|c|c|}
\hline Antifungal Agents & Drugs & Targets & Mechanisms & Administration Routes & Side Effects \\
\hline & Naftifine (NAF) & Trichophyton & & Topical & $\begin{array}{l}\text { No severe systemic side effects } \\
\text { Local irritation and uncommon } \\
\text { cases of allergic reaction [94] }\end{array}$ \\
\hline Antimetabolites & 5-flucytosine (5-FC) & $\begin{array}{l}\text { Candida spp., } \\
\text { Cryptococcus spp. }\end{array}$ & $\begin{array}{l}\text { Interrupts the pyrimidine } \\
\text { metabolism and inhibits RNA, } \\
\text { DNA, and protein synthesis }\end{array}$ & Systemic application & $\begin{array}{l}\text { Bone marrow suppression } \\
\text { Hepatic dysfunction } \\
\text { Diarrhea }\end{array}$ \\
\hline
\end{tabular}


Polyenes were isolated from Streptomyces spp., where they have functions in the bacterial defense mechanism. This class of drug mainly sequesters ergosterol and disrupts the fungal cell membrane via pore formation, resulting in leakage of cytoplasmic contents and fungal cell death $[95,96]$. The most potent, amphotericin B (AmB), is the most common polyene used for invasive fungal infections by forming an extra-membranous fungicidal sterol sponge that destabilizes membrane function [97]. In contrast with other kinds of polyenes, natamycin (NAT) inhibits fungal growth by reversibly inhibiting the amino acid and membrane transport proteins without altering the cell membrane permeability [85].

Enchinocandins target $\beta-1,3$-glucan synthase and negatively impact fungal cell wall integrity. These antifungal agents have good safety profiles, but have poor oral bioavailability, due to the lipid side chains. They have efficient therapeutic applications against both the planktonic cells of Candida and their biofilm formation. Additionally, this antifungal agent has been used to treat aspergillosis [98,99].

Allylamines inhibit squalene epoxidase activity and destroy the ergosterol synthesis pathway [100]. The fifth antifungal category agent is the antimetabolite 5-fluorocytosine (5-FC), which acts as a nontoxic prodrug and enters into fungal cells via the cytosine permease Fcy2. Furthermore, 5-FC can be converted into toxic 5-fluorouracil (5-FU) by cytosine deaminase Fcy1, which is only present in fungal cells. The UMP pyrophosphorylase transforms 5-FU to 5-fluorourdine monophosphate (5-FUMP), which incorporates into RNA and replaces UTP, thus inhibiting protein synthesis. Next, ribonucleotide reductase catalyzes 5-FUMP to 5-fluoro-2'-deoxyuridine-5'-monophosphate (5-FdUMP), which acts as a thymidylate synthase inhibitor and results in inhibition of fungal RNA and DNA synthesis.

\section{Unsatisfactory Properties of Currently Used Antifungal Drugs}

The five classes of conventional antifungal drugs have been determined to have great efficiency for treating both superficial and invasive fungal infection. Nevertheless, their side effects and unpleasant properties highly restrict their applications. As the most commonly used antifungal drugs in clinical practice, the major concerns of using azoles are their interactions with drugs that act as substrates for cytochrome P450, leading to off-target toxicity and fungal resistance to azoles [101,102]. Polyenes target fungal ergosterol, which is structurally similar to mammalian cholesterol. As a result, AmB displays devastating nephrotoxicity and infusion-related reactions $[103,104]$. As a result, its dosage is highly restricted, and it is usually replaced by an azole drug (voriconazole). Rather than invasive fungal infections, allylamines are normally used for treating superficial fungal infection, such as onychomycosis, which occurs in the fingernails or toenails [105].

As a highly effective antifungal agent, antimetabolite 5-FC is severely hepatoxic and results in bone-marrow depression [106-108]. Additionally, monotherapy with 5-FC triggers significant fungal resistance. Its primary clinical use is in combination with AmB for severe cases of candidiasis and cryptococcosis [109,110]. Although several effective antifungal agents have been prescribed for decades, their therapeutic outcomes remain unsatisfactory. Aside from these traditional antifungal agents being highly toxic, fungi tend to become resistant to them. Moreover, these antifungal agents display distinct efficiencies in tissue penetration and oral bioavailability.

In general, fluconazole, 5-FC, and voriconazole are small molecules and display better tissue penetration than the larger, more lipophilic agents (itraconazole) and amphipathic agents (AmB and echinocandins). Additionally, AmB and echinocandins exhibit delayed drug metabolism and accumulate in tissues [111]. Current strategies for improvement include developing analogs of these compounds, evaluating current drugs for their potential antifungal effects, finding new targets for antifungal drugs, and determining new fungal antigens as vaccine candidates [112,113].

Another possible strategy is using nanotechnology to modify or encapsulate currently used antifungal agents to improve their efficacy. To date, several nanomaterials have been investigated and presented as innovative antifungal agents, which include biodegradable polymeric and co-polymeric-based structures, metallic nanoparticles, metallic nanocompos- 
ites, and lipid-based nanosystems [114-116]. Additionally, the size range of nanoparticles endows them with the ability to deliver current antifungal agents by various routes of administration, such as oral, nasal, and intraocular routes [117].

\section{Nanotechnology-Based Therapies for Fungal Infections}

Since nano theory was firstly hypothesized by Richard Feynman in 1959, it has become a broad arena for integrating various areas of knowledge, such as biology, chemistry, physics, and engineering. Nanoscience has been shown to have great potential in the treatment of pathologies [118]. Moreover, nano-sized carriers enable the delivery of multiple drugs or imaging agents in the treatment of cancer or infections and in pathologic diagnostics $[119,120]$. The advantages of using nano-sized carriers include prolonged drug release, resistance to metabolic degradation, augmented therapeutic effects, and even avoidance of drug resistance mechanisms [119]. Metallic nanoparticles, mesoporous silica nanoparticles, polymeric nanoparticles, and lipid-based nanosystems are possible solutions to the challenges faced in the treatment of fungal infections. As the threat of invasive and superficial fungal infections continuously increases, hundreds of studies have led to a variety of synthesized and fabricated nanosystems for the optimization of antifungal therapy.

\section{Metallic Nanoparticles}

Metal nanoparticles are 1 to $100 \mathrm{~nm}$ in size and offer advantages of chemical stability, potential antifungal effects, low toxicity, and low pathogen resistance [121-124]. They can inhibit fungal cell membrane synthesis and certain fungal protein syntheses, as well as facilitate the production of fungal reactive oxygen species [125-128]. Gold, silver, zinc, and iron oxide nanoparticles are the most studied for antifungal drug delivery [121]. Several related studies are listed Table 3.

Nano-sized gold materials have been shown to have anti-candida effects with low toxicity $[129,130]$. Normally, gold nanoparticles are conjugated with effective agents to improve their antifungal effects. For example, indolicidin, a host defense peptide, was conjugated with gold nanoparticles to treat fluconazole-resistant clinical isolates of C. albicans. The indolicidin-gold nanoparticles did not show cytotoxicity for the fibroblast cells and erythrocytes and they significantly reduced the expression levels of the ERG11 gene in C. albicans [130].

Other methods of obtaining antifungal nanoparticles include the $\mathrm{SnCl}_{2}$ and $\mathrm{NaBH}_{4}$ based synthesis methods, which provide nanoparticles average sizes of $15 \mathrm{~nm}$ and $7 \mathrm{~nm}$, respectively. Interestingly, the smaller size of gold nanoparticles displayed better antifungal activity and greater biocidal action against Candida isolates than $15 \mathrm{~nm}$ gold nanoparticles by restricting the transmembrane $\mathrm{H}^{+}$efflux [131]. In another study, triangular gold nanoparticles were synthesized and conjugated with specific peptide ligands that inhibit secreted aspartyl proteinase 2 (Sap2) in C. albicans. Both non-conjugated and peptide gold nanoparticles showed high antifungal activity for 30 clinical isolates of C. albicans, although the peptide-conjugated nanoparticles had the highest uptake efficiency [129].

Silver nanoparticles have been shown to have great potential for antifungal growth and avoiding resistance in microorganisms [132]. As with gold, silver nanoparticles are easily modified and synthesized and display stable physicochemical characteristics [133]. Monotherapy with silver nanoparticles has been evaluated in various studies in vitro, where the growth and survival of $C$. albicans and $C$. tropicalis were significantly hampered. Moreover, they show great potential against fluconazole-resistant isolates of $C$. tropicalis in clinical settings. The antifungal efficiency of silver nanoparticles can be optimized when used in conjugation with AmB and fluconazole [134-136].

Silver and gold nanoparticles have also been biosynthesized to fight fungi-induced dermal infections. Interestingly, the growth of Candida, Microsporum, and Trichophyton dermatophyte isolates was inhibited by silver particles, but $C$. neoformans was susceptible to both gold and silver nanoparticles. Both of these heavy-metal-based nanoparticles were 
shown to lack cytotoxicity to human keratinocytes [137]. Despite its ability to impart anti-fungal activity, an overload of silver is toxic to mammalian cells, so the toxicity and use of silver nanoparticles needs further evaluation.

Aside from directly inhibiting the growth of fungal pathogens, a low dosage of silver nanoparticles has been demonstrated to have great potential for inhibiting mycotoxin biosynthesis [138]. Mycotoxin contamination has affected over $25 \%$ of the world's crops and leads to losses of around 1 billion metric tons of foods and food products annually according to the Food and Agriculture Organization of the United States. F. chlamydosporum and $P$. chrysogenum were used to produce biogenic silver nanoparticles, which inhibited the fungal growth of $A$. flavus and completely prevented its aflatoxin production [139]. $A$. terreus and $P$. expansum were also used to produce silver nanoparticles, which inhibited A. orchraceus and its mycotoxin production [140]. The uptake of these silver nanoparticles is believed to be localized to the endosomes. They are thought to significantly influence the fungal cells' oxidative stress response and secondary metabolism, as well as to increase transcripts of the superoxide dismutase, which is associated with aflatoxin inhibition [138].

Zinc-containing metallic nanoparticles are also commonly studied. Zinc oxide nanoparticles are considered the most promising of these for drug release and low toxicity [141-143]. As with silver nanoparticles, zinc nanoparticles show significant anti-candida effects both as a monotherapy $[144,145]$ and in combination with antifungal drugs such as fluconazole [146]. Thus far, the in vitro antifungal activities of zinc nanoparticles have been evaluated with various strains of C. albicans, C. krusei, C. aprapsilosis, and C. tropicalis [116,144,147]. However, the in vivo studies remain unconvincing; as a result, zinc nanoparticles are currently not indicated for the treatment of a specific candidiasis. Biomedical applications of iron oxide nanoparticles have also been widely investigated due to several attractive characteristics, including magnetism, biocompatibility, and stability $[148,149]$. Although this type of nanoparticle is mainly used in tissue imaging to assist the diagnosis, several studies indicate its great potential in treating antifungal infection. For example, Candida species are able to form a drug-resistant biofilm in medical apparatuses and instruments, such as catheters. Thus, Chifiriuc et al. synthesized oleic acid and $\mathrm{CHCl}_{3}$ fabricated iron oxide nanoparticles $\left(\mathrm{Fe}_{3} \mathrm{O}_{4}\right.$ /oleic acid: $\left.\mathrm{CHCl}_{3}\right)$ as a delivery system to carry essential oil from Rosmarinus officinalis and cover the catheter pieces. According to confocal laser scanning microscopy, they found that the essential oil and pulsed iron oxide nanoparticles significantly inhibited the fungal adherence of $C$. albicans and C. tropicalis. Furthermore, the same research group investigated these nanoparticles for their anti-bacterial capabilities by inhibiting the biofilm formation of Enterococcus faecalis [150,151].

Aside from anti-fungal effects, metallic nanoparticles have been used in fungal diagnoses [152]. The two common causes of human cryptococcosis, C. neoformans and C. gatti, have distinct pathogenic properties, so they require different therapeutic strategies. Detecting Cryptococcus in clinical specimens is time-consuming, and diagnosis is difficult. Artificial positively charged silver nanoparticles have been evaluated to directly distinguish between C. neoformans and C. gattii in clinical specimens using surface-enhanced Raman scattering and spectral analysis. These nanoparticles resulted in better signals than the standard substrate of negatively charged silver nanoparticles in that they selfassembled on the surface of the cryptococcal cell walls via electrostatic aggregation. This novel method based on silver nanoparticles was 100\% accurate in distinguishing between the two Cryptococcus species. 
Table 3. Metallic Nanoparticle based antifungal therapeutic strategies.

\begin{tabular}{|c|c|c|c|c|c|}
\hline Nanosystems & Active Antifungal Agents & Pathogens & Target Diseases & Antifungal Mechanisms and Outcomes & References \\
\hline Triangular gold nanoparticles & Antifungal peptides & $\begin{array}{l}\text { Thirty clinical isolates of } \\
\text { C. albicans from patients with } \\
\text { vaginal candidiasis }\end{array}$ & Vaginal candidiasis & $\begin{array}{l}\text { Antifungal effects were achieved via } \\
\text { conjugating nanoparticles with peptide } \\
\text { ligands that inhibit secreted aspartyl } \\
\text { proteinase } 2 \text { (Sap2) in C. albicans }\end{array}$ & [129] \\
\hline Gold nanoparticles & Indolicidin & $\begin{array}{l}\text { Ten fluconazole-resistant clinical } \\
\text { isolates of } C \text {. albicans in } \\
\text { skin lesions }\end{array}$ & C. albicans caused burn infection & $\begin{array}{l}\text { Conjugated indolicidin with gold } \\
\text { nanopartilces significantly reduced the } \\
\text { expression levels of the } E R G 11 \text { gene in } \\
\text { fluconazole-resistant isolates of } C \text {. albicans } \\
\text { and } i N O S \text { gene in macrophage }\end{array}$ & [130] \\
\hline Biogenic silver nanoparticles & Amphotericin B (AmB) & C. albicans, C. tropicalis & Anti-fungal growth & $\begin{array}{l}\text { Amphotericin B-conjugated silver } \\
\text { nanoparticles with more activity in } \\
\text { inhibiting C. albicans and C. tropicalis as } \\
\text { compared to AmB only }\end{array}$ & [135] \\
\hline $\begin{array}{l}\text { Silver/silver } \\
\text { chloride nanopartilces }\end{array}$ & Latex of Azadirachta indica & $\begin{array}{l}\text { Sensitive and resistant strains of } \\
\text { C. tropicalis }\end{array}$ & $\begin{array}{l}\text { Inhibited fungal growth and } \\
\text { biofilm formation }\end{array}$ & $\begin{array}{l}\text { Latex fabricated silver/silver chloride } \\
\text { nanoparticles inhibited fungal growth and } \\
\text { biofilm formation }\end{array}$ & [136] \\
\hline $\begin{array}{l}\text { Biogenic gold and } \\
\text { silver nanoparticles }\end{array}$ & $\begin{array}{l}\text { The high astaxanthin content } \\
\text { yeast, Phaffia rhodozyma, is } \\
\text { utilized for microbe-assisted } \\
\text { nanoparticle synthesis }\end{array}$ & $\begin{array}{l}\text { C. albicans, C. glabrata, C. krusei, } \\
\text { C. parapsilosis, C. tropicalis, } \\
\text { C. neoformans, M. gypseum, } \\
\text { T. mentagrophytes, T. tonsurans }\end{array}$ & $\begin{array}{l}\text { Treat for superficial } \\
\text { cutaneous mycosis }\end{array}$ & $\begin{array}{l}\text { Biogenic silver nanoparticles displayed } \\
\text { significantly antifungal effects to } \\
\text { Cryptococcus, Candida, Microsporum, and } \\
\text { Trichophyton dermatophytes, while gold } \\
\text { nanoparticles only showed antifungal } \\
\text { effects to Cryptococcus }\end{array}$ & [138] \\
\hline
\end{tabular}


Table 3. Cont.

Nanosystems

Active Antifungal Agents

Pathogens

Target Diseases

Antifungal Mechanisms and Outcomes

The MIC results for A. flavus were 48,45 ,

and $50 \mu \mathrm{g} / \mathrm{mL}$ for Fusarium

synthesizedsilver nanoparticles (FAgNPs),

Penicillium synthesizedsilver nanoparticles

(PAgNPs), and itraconazole, respectively.

For A. ochraceus, FAgNPs, PAgNPs, and

itraconazole displayed MIC values of 51, 47,

Biogenic silver nanoparticles by F. chlamydosporus (Fusarium-silver nanoparticles) or P. chrysogenum (Penicillium-silver nanoparticles)
Silver nanoparticles

A. flavus, A. ochraceus
Anti-fungal growth and inhibit aflatoxin production
FAgNPs and PAgNPs completely inhibit the

aflatoxin production by $A$. flavus and the

MIC values were 5.9 and $5.6 \mu \mathrm{g} / \mathrm{mL}$,

respectively, 6.3 and $6.1 \mu \mathrm{g} / \mathrm{mL}$ of the

A. ochraceus produced ochratoxin A was

inhibited by FAgNPs and

PAgNPs, respectively.

\begin{tabular}{|c|c|c|c|c|c|}
\hline Zinc oxide nanoparticles & Fluconazole & $\begin{array}{l}\text { C. albicans isolated from } \\
\text { vaginal samples }\end{array}$ & Vulvovaginal candidiasis & $\begin{array}{l}\text { Fluconazole conjugated zinc oxide } \\
\text { nanoparticles displayed anti-candida } \\
\text { growth effects }\end{array}$ & [146] \\
\hline Zinc oxide nanoparticles & Nystatin & $\begin{array}{l}\text { C. albicans isolated from } \\
\text { Vulvovaginal Candidiasis }\end{array}$ & Vulvovaginal candidiasis & $\begin{array}{l}\text { Nystatin conjugated zinc oxide } \\
\text { nanoparticles anti-candida growth via } \\
\text { inhibiting the expression of fungal } \\
\text { SAP1-3 genes }\end{array}$ & [147] \\
\hline $\begin{array}{l}\text { Oleic acid and } \mathrm{CHCl}_{3} \text { fabricated } \\
\text { iron oxide nanoparticles } \\
\left(\mathrm{Fe}_{3} \mathrm{O}_{4} / \text { oleic acid: } \mathrm{CHCl}_{3}\right)\end{array}$ & Rosmarinus officinalis essential oil & C. albicans and C. tropicalis & $\begin{array}{l}\text { Biofilm formation in the medical } \\
\text { apparatus and instruments }\end{array}$ & $\begin{array}{l}\text { The essential oil pulsed iron oxide } \\
\text { nanoparticles significantly inhibit fungal } \\
\text { adherence of C. albicans and C. tropicalis. } \\
\text { Thus, they inhibit the biofilm formation in } \\
\text { the medical instruments }\end{array}$ & [150] \\
\hline Gold and silver nanoparticles & Heparin & C. albicans, C. krusei, C. parapsilosis & Anti-fungal growth & $\begin{array}{l}\text { Silver-Heparin conjugated nanoparticles } \\
\text { displayed antifungal effects, instead of } \\
\text { gold-Heparin conjugated nanoparticles }\end{array}$ & [153] \\
\hline Zinc oxide nanoparticles & $\mathrm{N} / \mathrm{A}$ & $\begin{array}{l}125 \text { clinical isolates of } \text { C. albicans } \\
\text { from patients with urinary } \\
\text { tract infections }\end{array}$ & $\begin{array}{l}\text { C. albicans caused urinary } \\
\text { Tract Infections }\end{array}$ & $\begin{array}{l}\text { Zinc oxide nanoparticles displayed } \\
\text { antifungal effects to } 125 \text { clinical isolated } \\
\text { C. albicans strains (include } \\
10 \text { fluconazole-resistant strains) via } \\
\text { inhibiting the fungal } A L S 1 \text { and } A L S 3 \\
\text { gene expression }\end{array}$ & [154] \\
\hline
\end{tabular}




\section{Mesoporous Silica Nanoparticles}

Mesoporous silica nanoparticles (MSNs) were firstly developed in the early 1990s and have been shown to have potential applications in areas of biomedicine, such as drug delivery, disease diagnosis, medical imaging, and tissue regeneration [155-157]. MSNs are fascinating in drug delivery because they are biocompatible, they are highly chemically and thermally stable, and they provide a large surface area for carrying drug payloads. Moreover, bioactive components can be assembled on the nanoparticle surface and guide the drug-loaded system directly to a specific location [158]. Thus, MSNs have been developed as novel drug delivery systems in the treatments of various diseases [158-160]. Table 4 shows a summary of several successful studies that use this nanomaterial in drug delivery systems for treating fungal infections.

Table 4. Mesoporous Silica Nanoparticle based antifungal therapeutic strategies.

\begin{tabular}{|c|c|c|c|c|c|}
\hline Nanosystems & $\begin{array}{c}\text { Active } \\
\text { Antifungal Agents }\end{array}$ & Pathogens & Target Diseases & $\begin{array}{l}\text { Antifungal Mechanisms } \\
\text { and Outcomes }\end{array}$ & References \\
\hline $\begin{array}{l}\text { pH-sensitive gated } \\
\text { mesoporous } \\
\text { silica nanoparticles }\end{array}$ & Tebuconazole & S. cerevisiae & Anti-fungal growth & $\begin{array}{l}\text { Tebuconazole loaded } \\
\text { mesoporous silica } \\
\text { nanoparticles enable } \\
\text { sensing of the } \\
\text { environmental pH } \\
\text { alteration and release the } \\
\text { fungal agent for } \\
\text { antifungal effects }\end{array}$ & [161] \\
\hline $\begin{array}{l}\text { Hexagonal mesoporous } \\
\text { silica nanoparticle with } \\
\text { aminopropyl groups }\end{array}$ & Econazole & C. albicans & $\begin{array}{l}\text { Topical fungal } \\
\text { infection }\end{array}$ & $\begin{array}{l}\text { Dermal administration of } \\
\text { econazole loaded } \\
\text { mesoporous silica } \\
\text { nanoparticles displayed } \\
\text { antifungal effects to } \\
\text { C. albicans in vitro and } \\
\text { in vivo }\end{array}$ & [162] \\
\hline $\begin{array}{l}\text { Nanoflowers polylactic } \\
\text { acid added with } \\
\text { mesoporous } \\
\text { silica nanoparticles }\end{array}$ & Levofloxacin & $\begin{array}{l}\text { S. aureus, E. coli, } \\
\text { C. albicans, A. niger }\end{array}$ & Anti-fungal growth & $\begin{array}{l}\text { The anti-microbial effect of } \\
\text { Levofloxacin was enhanced } \\
\text { by functionalized } \\
\text { mesoporous silica } \\
\text { nanoparticles with } \\
\text { lactic acid }\end{array}$ & [163] \\
\hline
\end{tabular}

pH-sensitive gated MSNs were synthesized for carrying tebuconazole. The assembled nanosystem significantly inhibited yeast growth and could possibly provide an optimal treatment for vaginal mycoses [161]. Furthermore, econazole incorporated into an MSN system has been demonstrated to have antifungal activity against $C$. albicans [162]. Aside from treatment strategies, MSN systems have also been used to study the functionality of macrophages in fungal infections. Portoles et al. developed mesoporous $\mathrm{SiO}_{2}-\mathrm{CaO}$ nanospheres that were labeled with fluorescein isothiocyanate (FITC-NanoMBGs), and the red fluorescence signal from this fluorescent-labeled MSN system was used to measure the ability of $C$. albicans to carry out phagocytosis. This provides a critical method for evaluating the macrophage-fungus interface and offers a perspective for understanding host immunity responses during fungal infections [164].

The controlled release of a drug is considered one of the most attractive improvements in anti-fungi therapeutic strategies. Polylactic acid was coated with functionalized MSNs, and this nanosystem was conjugated with levofloxacin to form an MSN-based drug delivery system. In vitro antimicrobial tests showed that this MSN-based nanosystem had significant anti-microbial properties against Staphylococcus aureus, E. coli, and C. albicans. However, this nanosystem was not effective in preventing the growth of $A$. niger. Nevertheless, this nanosystem was shown to have acceptable cytotoxicity to normal human fibroblasts [163].

MSNs have also been used in combination with metallic nanoparticles, which enhance the fungicidal effects. In 2016, a laboratory from Spain developed a nanosystem that utilized 
electrospun cellulose acetate to contain silver and copper nanoparticles and supported it with sepiolite and mesoporous silica. This resulted in significantly fungistatic membranes against Aspergillus niger [165]. The controlled release of metal was facilitated by the MSNs. Thus, the antifungal effects were optimized by the synergic use of metallic nanoparticles and MSNs.

Although the cytotoxicity of MSN-based antifungal treatments is acceptable $[161,163]$, overloads of antifungal drugs or heavy metals lead to severe side effects. Thus, the use of naturally isolated antimicrobial agents might be the optimum antifungal therapy. Klouček's research group loaded an essential oil component, eugenol, into MSNs and capped them with various saccharide gates, such as starch, maltodextrin, maltose, and glucose. In vitro experiments showed that the eugenol-loaded MSN system inhibited the growth of $A$. niger and that the release of eugenol could occur through the degradation of the anchored saccharides by exogenous enzymes.

\section{Polymeric Nanoparticles}

Polymeric nanoparticles (PNs) were first developed in the 1970s, and range in size from 5 to $1000 \mathrm{~nm}$. Active ingredients such as antifungal drugs can be loaded by either entrapping them inside the particle or adsorbing them onto polymeric cores. Polymeric nanoparticles are divided into two classes, based on their morphological properties: nanocapsules and nanospheres [166]. A nanocapsule is covered by a polymeric wall and has oil or water in the core, whereas a nanosphere is made up of a continuous polymer network that can retain a drug inside or absorb it onto the surface [166-168]. Thus, nanocapsules and nanospheres can be considered reservoir systems and matrix systems, respectively. Several production methods have been used, including polyelectrolytic complexation, ionotropic gelation, and emulsification by evaporation, solvent diffusion, solvent evaporation, or nanoprecipitation [169-172].

The efficiency of drug dispersion into PNs is determined by several factors, including the physicochemical characteristics of the drug, nanoparticle surface characteristics, the nature of the polymer, and the amount of drug to be loaded. Thus, natural oils and polymeric surface surfactants are used to improve the drug payload in PNs $[173,174]$. The advantages of PN-based treatments include enhanced therapeutic efficiency and penetration, reduced toxicity, and the delivery of drug action to a target site [175]. This nanosystem has been investigated as an effective therapeutic strategy for treating fungal infections, typically with drugs that are already in use (Table 5). 
Table 5. Polymeric Nanoparticle based antifungal therapeutic strategies.

\begin{tabular}{|c|c|c|c|c|c|}
\hline Nanosystems & Active Antifungal Agents & Pathogens & Target Diseases & Antifungal Mechanisms and Outcomes & References \\
\hline $\begin{array}{l}\text { Poly-lactic acid and dextran } \\
\text { sulfate synthesized } \\
\text { polymeric nanoparticles }\end{array}$ & Curcumin & $\begin{array}{l}\text { C. albicans were inoculated in } \\
\text { mice tongues }\end{array}$ & Oral candidiasis & $\begin{array}{l}\text { Polymeric nanoparticles improved the hydrophilicity } \\
\text { of curcumin and significantly inhibited the } \\
\text { colony-forming unit of C. albicans in mouse } \\
\text { tongue tissues }\end{array}$ & [176] \\
\hline Chitosan nanoparticles & $\mathrm{N} / \mathrm{A}$ & C. albicans C. tropicalis, C. krusei & Anti-biofilm formation & $\begin{array}{l}\text { Chitosan nanoparticles displayed significant } \\
\text { fungicidal effects in Candida and inhibited its } \\
\text { biofilm formation }\end{array}$ & [177] \\
\hline $\begin{array}{l}\text { Polycaprolactone nanoparticles } \\
\text { with two forms: nanocapsules } \\
\text { (NC) and nanospheres (NS) }\end{array}$ & Itraconazole & $\begin{array}{l}\text { C. albicans were inoculated in } \\
\text { mice vagina }\end{array}$ & Vulvovaginal candidiasis & $\begin{array}{l}\text { Only itraconazole loaded NC significantly decreased } \\
\text { fungal load in mice vaginal tissue, instead of } \\
\text { itraconazole loaded NS }\end{array}$ & {$[178]$} \\
\hline $\begin{array}{l}\text { Chitosan-based } \\
\text { polymeric nanoparticles }\end{array}$ & Miconazole & $\begin{array}{l}\text { C. albicans were inoculated in } \\
\text { mice vagina }\end{array}$ & Vulvovaginal candidiasis & $\begin{array}{l}\text { Miconazole loaded chitosan-based polymeric } \\
\text { nanoparticles displayed same therapeutic effects to } \\
\text { miconazole; however, nanoparticles only } \\
\text { encapsulated one seventh of miconazole concentration }\end{array}$ & [179] \\
\hline Chitosan nanoparticles & Farnesol and miconazole & $\begin{array}{l}\text { C. albicans were inoculated in } \\
\text { mice vagina }\end{array}$ & Vulvovaginal candidiasis & $\begin{array}{l}\text { Farnesol and miconazole loaded } \\
\text { chitosan-nanoparticles not only inhibited fungal } \\
\text { growth, but hampered yeast to hyphae transition }\end{array}$ & [180] \\
\hline $\begin{array}{l}\text { Eudragit RL100 nanoparticles } \\
\text { coated with hyaluronic acid } \\
\text { (EUD nanoparticles /HA) }\end{array}$ & Amphotericin B (AmB) & $\begin{array}{l}\text { C. albicans were inoculated in } \\
\text { mice vagina }\end{array}$ & Vulvovaginal candidiasis & $\begin{array}{l}\text { AmB EUD nanoparticles/HA enable to penetrate into } \\
\text { the vaginal epithelium via CD } 44 \text { receptor and } \\
\text { eliminated of } 100 \% \text { of the vaginal fungal burden } \\
\text { within } 24 \mathrm{~h}\end{array}$ & [181] \\
\hline $\begin{array}{l}\text { Poly (lactide-co-glycolide) } \\
\text { (PLGA) or poly } \\
\text { (lactide-co-glycolide)-poly } \\
\text { (ethylene glycol) (PLGA-PEG) } \\
\text { blend nanoparticles }\end{array}$ & Amphotericin B (AmB) & C. albicans, C. neoformans & Anti-fungal growth & $\begin{array}{l}\text { AmB loaded PLGA-PEG nanoparticles only displayed } \\
\text { antifungal effects to C. albicans, not to C. neoformans. } \\
\text { Moreover, AmB loaded PLGA-PEG not showed liver } \\
\text { and renal damage }\end{array}$ & [182] \\
\hline Chitosan nanoparticles & $\begin{array}{l}\text { Bioactive peptide from Tityus } \\
\text { stigmurus scorpion (TistH) }\end{array}$ & $\begin{array}{l}\text { C. albicans, C. parapsilosis, } \\
\text { C. tropicalis, C. krusei }\end{array}$ & $\begin{array}{l}\text { Inhibit fungal growth and } \\
\text { biofilm formation }\end{array}$ & $\begin{array}{l}\text { TistH-Chitosan nanoparticles inhibited C. albicans, } \\
\text { C. parapsilosis, and C. tropicalis, and also reduced the } \\
\text { biofilm formation of C. tropicalis, C. krusei, and } \\
\text { C. albicans }\end{array}$ & [183] \\
\hline $\begin{array}{l}\text { Polybutylcyanoacrylate } \\
\text { nanoparticles (PBCA-NA) }\end{array}$ & Amphotericin B (AmB) & $\begin{array}{l}\text { C. neoformans induced } \\
\text { meningoencephalitis in } \\
\text { mouse model }\end{array}$ & $\begin{array}{l}\text { Cryptococcal } \\
\text { meningoencephalitis }\end{array}$ & $\begin{array}{l}\text { The intravenous administration of AmB-PBCA-NP } \\
\text { enabled crossing the blood brain barrier and reduced } \\
\text { the colony-forming unit counts of cryptococcal } \\
\text { meningoencephalitis mouse model. }\end{array}$ & [184] \\
\hline $\begin{array}{l}\text { Poly (lactic-co-glycolic acid) } \\
\text { nanoparticles with fungal } \\
\text { chitosan-binding peptide }\end{array}$ & Itraconazole & C. neoformans & Cryptococcal pneumonia & $\begin{array}{l}\text { Polymeric nanoparticle carried cryptococcal } \\
\text { chitosan-binding peptide specific recognized and bind } \\
\text { to fungal capsules, and thus precisely delivered the } \\
\text { itraconazole to clear the } C \text {. neoformans from mice lungs }\end{array}$ & [185] \\
\hline
\end{tabular}


To improve the therapeutic effects of antifungal agents, PNs have been widely used in the treatment of candidiasis, including oral candidiasis $[176,177,186]$ and vaginal candidiasis [178-182]. In the former, chitosan was incorporated into PNs, resulting in inhibition of the biofilm adhesion and formation of Candida. Chitosan-PNs significantly inhibited Candida biofilm formation and decreased the number of colony forming units of Candida spp., in contrast with $\mathrm{NaOCl}$, which was used as a positive control [177].

In other cases, PNs were used to optimize antifungal therapies by taking advantage of the large contact surface of the vagina, on which local or systemic fungal infections are obtained. Because it has a broad spectrum of action, itraconazole is a common treatment for vaginal fungal infections. In an attempt to optimize itraconazole treatment, the drug was loaded onto both nanocapsules and nanospheres, which improved the encapsulation efficiency. In a mouse model of vaginal Candida infection, itraconazole-loaded nanocapsules significantly reduced fungal infection, whereas loaded nanospheres did not. Histological analysis indicated that mice treated with the loaded nanospheres had augmented levels of IL-1 $\beta$ and TNF- $\alpha$ and typical tissue inflammation. This showed that the nanocapsules were a more ideal means of improving vulvovaginal candidiasis and a host of immune responses [178].

Another common antifungal drug used for vaginal candidiasis is AmB. In one recent study, nanoprecipitation was used to load AmB onto Eudragit RL100 nanoparticles coated with hyaluronic acid. The Eudragit RL100 nanoparticles facilitated 81\% AmB release that lasted for $96 \mathrm{~h}$, although the vaginal fungal burden was eliminated within $24 \mathrm{~h}$. Thus, this PN system provided an optimized drug release platform that significantly promotes antifungal effects. Moreover, this study suggested that the innovative PNs facilitate AmB penetration into the vaginal epithelium via CD44 receptors, rendering this treatment a great improvement over conventional PNs and thus representing a novel vaginal means of optimizing vulvovaginal candidiasis treatment [181].

Polymeric nanoparticles have also displayed low toxicity in murine fibroblasts [180], human keratinocytes [187], kidney epithelial cells, and murine macrophages [183]. Consequently, they can provide nanosystems for optimized treatment of candidiasis. Cryptococcus infections have similarly been treated using PNs. In one case, AmB was loaded onto polybutylcyanoacrylate nanoparticles, which have a great ability to cross the blood-brain barrier (BBB), resulting in an effective treatment for cryptococcal meningoencephalitis. The loaded nanoparticles significantly increased the survival rate of BALB/c mice with cryptococcal infections, and the number of colony-forming units was much lower in the brain tissues of mice treated with nanoparticles compared to those treated with AmB alone. Thus, PNs have great potential for delivering antifungal drugs across the BBB as treatments for encranial infections [184].

The pulmonary region is another infection site for cryptococcosis, where the pulmonary mucus layer is the first point of contact with $C$. neoformans. In order to eliminate Cryptococcal related pulmonary infection, Li and Liao's team developed a sophisticated drug carrier based on chitosan-conjugated poly (lactic-co-glycolic acid, PLGA) nanoparticles [185]. Chitosan is not only part of the ectocellular structure of Cryptococcus neoformans, but also a typical biomaterial for improving drug oral absorption. Thus, they firstly utilized the phage display library to select a chitosan-binding peptide (12-mer peptide: ADGVGDAESRTR, CP) that covalently conjugates to PLGA to form CP-PLGA NPs. This was followed by incubation with free chitosan in vitro to form chitosan covered nanoparticles, which were referred to as C-CP-PLGA NPs.

The outer and noncovalent chitosan is responsible for enhancing the CP-PLGA NPs' permeability across the oral absorption barrier. Furthermore, bound chitosan enhances the adhesion to the mucosal layer. The CP-PLGA NPs can be released into circulation to research an infection site. After loading the itraconazole (ITZ) into PLGA, both CPLGA/ITZ and C-CP-PLGA/ITZ showed remarkable clearing capability for cryptococcal lung infections and increased the survival rate of mice. However, the mortality of C-CP- 
PLGA/ITZ treated cryptococcsis mice was significantly lower than that of C-PLGA/ITZ treated mice [185].

\section{Lipid Based Nanoparticles}

Lipid-based nanosystems are also excellent drug delivery tools for treating fungal infections, reaching therapeutic targets, and providing effective delivery systems (Figure 2).

Liposomes were firstly developed as double-layer lipid systems for drug delivery in 1965. Phospholipids are the primary chemical component of the liposomal structure and offer both hydrophobic and hydrophilic characteristics. Artificial liposomal structures are primarily cholesterol, which provides advantages such as promising stability, moderation of the fluidity of the lipid bilayer, controlled drug release, and stabilization of the vesicles [188-190]. These constituents give liposomal structures the ability to incorporate drugs of various polarities: hydrophilic substances are encapsulated in the aqueous region, but hydrophobic substances are held inside the liposome [191].

Liposome nanoparticles are easily fabricated and modified to improve the therapeutic effects of antifungal drugs. The advantages of liposomal nanoparticles also include good biocompatibility and biodegradability. Additionally, they have considerable therapeutic potential and have desirable pharmacokinetics and pharmacodynamics, providing sustained drug release and reduced toxicity [192]. As a result, liposomes are widely utilized as primary delivery vehicles for pharmaceuticals [193-195]. Table 6 showed several studies that utilized liposome nanoparticles for treating fungal infections. 


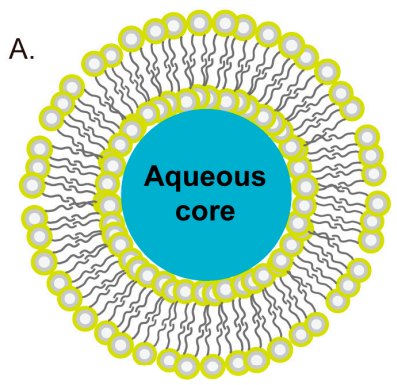

Liposome

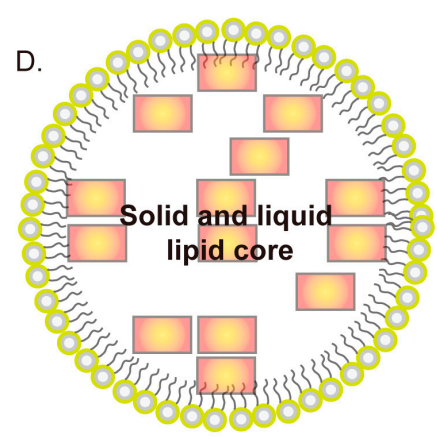

Nanostructured lipid nanocarrier

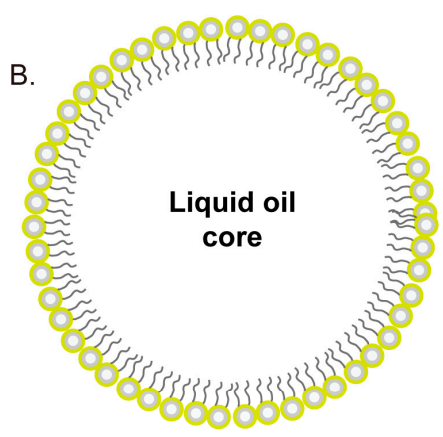

Nanoemulsions

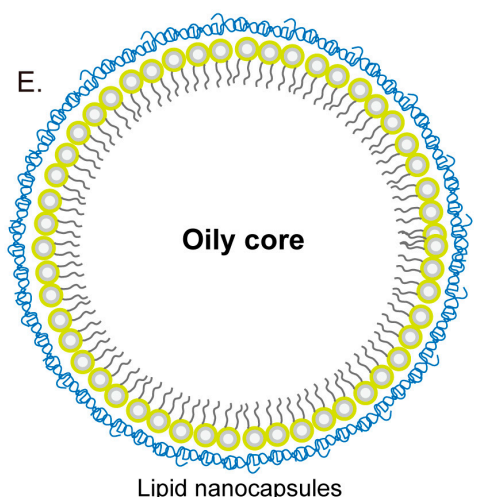

Solid lipid

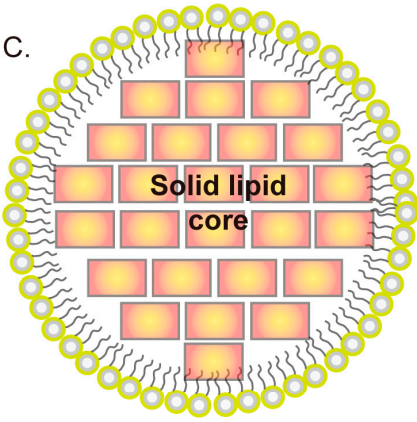

Solid lipid nanoparticles

Hydrophilic head

Hydrophobic tail

Figure 2. Schematic representation of lipid-based nanosystems. (A) Liposomes are developed as double-layer lipid systems that consist of phospholipid layers and aqueous core. (B) Nanoemulsions (NEs) are dispersed nanosystems that consist of a single layer of phospholipid and two types of core, either oil-in-water or water-in-oil. This system is always stabilized with an appropriate surfactant. The size of NEs is typically smaller than $500 \mathrm{~nm}$. (C) Solid Lipid Nanoparticle (SLNs) with submicron sizes that range from 50 to $100 \mathrm{~nm}$. SLNs are similar to NEs, but SLNs contain the solid lipid core that offers the enhanced drug release control and system stability. (D) Nanostructured Lipid Carriers (NLCs) are considered the second generation of SLN, which contain a hydrophobic nucleus dispersed in an aqueous environment and stabilized by surfactant molecules. It contains both a liquid and solid lipid core that facilitate drug release control and reduce drug expulsion during development and storage. (E) Lipid Nanocapsules (LNCs) were the newest developed particles ranging from 20 to $100 \mathrm{~nm}$, and consist of an oily nucleus of medium-chain of triglycerides and are surrounded by a shell of PEGylated surfactant and lecithin. 
Table 6. Lipid Nanoparticle based antifungal therapeutic strategies.

\begin{tabular}{|c|c|c|c|c|c|}
\hline Nanosystems & Active Antifungal Agents & Pathogens & Target Diseases & Antifungal Mechanisms and Outcomes & References \\
\hline $\begin{array}{l}\text { Sodium cholesteryl sulfate lipid } \\
\text { complex with Amphotericin B, as } \\
\text { referred to ABCD }\end{array}$ & Amphotericin B (AmB) & $\begin{array}{l}174 \text { patients with } \\
\text { invasive aspergillosis }\end{array}$ & Invasive aspergillosis & $\begin{array}{l}\text { The drug-related toxicity was evaluated via } \\
\text { comparing between ABCD and AmB recipients, } 53 \% \\
\text { vs } 30 \% \text { (chills), } 27 \% \text { vs } 16 \% \text { (fever), } 1 \% \text { vs } 4 \% \\
\text { (hypoxia), and } 22 \% \text { vs } 24 \% \text { (toxicity requiring study } \\
\text { drug discontinuation). The antifungal efficiency was } \\
\text { equivalent between ABCD and AmB }\end{array}$ & [196] \\
\hline AmB lipid complex (ABLC) & Amphotericin B (AmB) & $\begin{array}{l}556 \text { patients with fungal infection } \\
\text { and intolerant of conventional } \\
\text { antifungal therapy. }\end{array}$ & Invasive fungal infection & $\begin{array}{l}\text { There were } 57 \% \text { of patients with responses to ABLC, } \\
\text { including } 42 \% \text { ( } 55 \text { ) of } 130 \text { cases of aspergillosis, } 67 \% \\
\text { ( } 28 \text { ) of } 42 \text { cases of disseminated candidiasis, } 71 \% \text { (17) } \\
\text { of } 24 \text { cases of zygomycosis, and } 82 \% \text { (9) of } 11 \text { cases } \\
\text { of fusariosis }\end{array}$ & [197] \\
\hline $\begin{array}{l}\text { Nanoliposome with RDP } \\
\text { (peptide derived from rabies } \\
\text { virus glycoprotein for } \\
\text { brain-targeting) }\end{array}$ & $\begin{array}{l}\text { Fluorescent polypyridyl } \\
\text { ruthenium complex RC-7 }\end{array}$ & $\begin{array}{l}\text { Cryptococcal } \\
\text { meningoencephalitis animal } \\
\text { model with } \\
\text { C. neoformans infection }\end{array}$ & $\begin{array}{l}\text { Cryptococcal } \\
\text { meningoencephalitis }\end{array}$ & $\begin{array}{l}\text { RC-7-RDP nanosystem remarkably prolonged the } \\
\text { survival days of the meningoencephalitis-bearing } \\
\text { mice from } 10 \text { days to } 24 \text { days. }\end{array}$ & [198] \\
\hline Nanoemulsions (NE) & $\begin{array}{l}\text { Geranium oil (GO) from } \\
\text { Pelargonium graveolens }\end{array}$ & $\begin{array}{l}\text { C. albicans, C. tropicalis, C. glabrata, } \\
\text { C. krusei }\end{array}$ & $\begin{array}{l}\text { Inhibit fungal growth and } \\
\text { biofilm formation }\end{array}$ & $\begin{array}{l}\text { GO loaded nanoemusions inhibited growth and } \\
\text { biofilm formation of Candida spp., except C. krusei } \\
\text { biofilm formation with strong resistance to GO-NE }\end{array}$ & [199] \\
\hline Nanoemulsions (NE) & Clove oil (CO) & C. albicans, C. glabrata & Anti-fungal growth & Nanoemulsions enhanced antifungal effects of $\mathrm{CO}$ & [200] \\
\hline Nanoemulsions (NE) & Nystatin & C. albicans & Buccal candidiasis & $\begin{array}{l}\text { Nystatin loaded nanoemulsion displayed } \\
\text { anti-candida effects }\end{array}$ & [202] \\
\hline Nanoemulsions (NE) & Nystatin & C. albicans, S. cerevisiae & Skin fungal infection & $\begin{array}{l}\text { Nanoemulsion sustained the release of nystatin and } \\
\text { the antifungal drug was not absorbed into systemic } \\
\text { circulation and sufficiently eliminated dermal } \\
\text { C. albicans. Thus, this nanoemulsion system } \\
\text { enhanced the nystatin therapy for skin candidiasis }\end{array}$ & [203] \\
\hline Nanoemulsions (NE) & $\begin{array}{l}\text { Ketoconazole with clove } \\
\text { oil (CL-KTZ) }\end{array}$ & C. albicans & Anti-fungal growth & $\begin{array}{l}\text { The fungal membrane integrity and growth were } \\
\text { decreased in NE-CL-KTZ treated group and the } \\
\text { nanoemulsions improved KTZ release more than } \\
\text { nine times when compared to KTZ cream }\end{array}$ & [204] \\
\hline Nanoemulsions (NE) & Amphotericin B (AmB) & C. albicans, A. niger & Skin candidiasis and aspergillosis & $\begin{array}{l}\text { NE enhanced AmB to cross the stratum corneum } \\
\text { barrier in rat skin and displayed better fungicidal } \\
\text { effects than AmB and Fungisome }{ }^{\mathrm{TM}} \text { (commercial } \\
\text { antifungal drug). }\end{array}$ & [205] \\
\hline
\end{tabular}


Table 6. Cont

\begin{tabular}{|c|c|c|c|c|c|}
\hline Nanosystems & Active Antifungal Agents & Pathogens & Target Diseases & Antifungal Mechanisms and Outcomes & References \\
\hline $\begin{array}{l}\text { Nanoemulsions (NE) with } \\
\text { thioglycolic acid as } \\
\text { permeation enhancer }\end{array}$ & Ketoconazole & C. albicans, T. rubrum & Onychomycosis & $\begin{array}{l}\text { Ketoconazole-NE contained permeation enhancer } \\
\text { that displayed antifungal effects for onychomycosis }\end{array}$ & [206] \\
\hline Solid lipid nanoparticles & Fluconazole & $\begin{array}{l}\text { Fluconazole-resistant strains of } \\
\text { C. albicans }\end{array}$ & Anti-fungal growth & $\begin{array}{l}\text { Solid lipid nanoparticle promoted the fluconazole } \\
\text { release and enhanced antifungal effects to } \\
\text { C. albicans, C. parapsilosis, C. glabrata }\end{array}$ & [207] \\
\hline $\begin{array}{l}\text { Solid lipid nanoparticles (SLN) } \\
\text { with hydrogel }\end{array}$ & Miconazole & $\begin{array}{l}\text { C. albicans were inoculated into } \\
\text { dermal side of skin in } \\
\text { mouse model }\end{array}$ & Skin candidiasis & $\begin{array}{l}\text { This SLN-hydrogel system provided sustained } \\
\text { release of miconazole and displayed antifungal } \\
\text { effects to C. albicans both in vitro and in vivo }\end{array}$ & [208] \\
\hline $\begin{array}{l}\text { Solid lipid nanoparticles (SLN) } \\
\text { with hydrogel }\end{array}$ & Ketoconazole (KCZ) & $\begin{array}{l}\text { C. albicans were inoculated to the } \\
\text { skin in mouse model }\end{array}$ & Skin candidiasis & $\begin{array}{l}\text { KCZ-SLN exhibited a sustained drug release over } \\
24 \mathrm{~h} \text { and inhibited topical fungal infection }\end{array}$ & [209] \\
\hline $\begin{array}{l}\text { Solid lipid nanoparticles (SLN) } \\
\text { conjugated with } \\
\text { polyoxyethylene-40 stearate } \\
\text { (PEG-40 stearate) }\end{array}$ & $\begin{array}{l}\text { Ketoconazole }(\mathrm{KCZ}) \\
\text { and clorimazole }\end{array}$ & C. albicans & Vulvovaginal candidiasis & $\begin{array}{l}\text { SLN conjugated PEG- } 40 \text { facilitated the stabilization } \\
\text { of antifungal agents and enhanced fungicidal effects }\end{array}$ & [210] \\
\hline Lipid-based nanoparticles (LNP) & Voriconazole & C. glabrata, A. flavus & $\begin{array}{l}\text { Ophthalmic candidiasis } \\
\text { and aspergillosis }\end{array}$ & $\begin{array}{l}\text { LNP improved the poor solubility of voriconaole } \\
\text { and enhanced its antifungal effects }\end{array}$ & [211] \\
\hline Solid lipid nanoparticles (SLN) & Amphotericin B (AmB) & C. albicans & Oral candidiasis & $\begin{array}{l}\text { SLN improved AmB oral bioavailability and } \\
\text { alleviated its toxicity, and it enhanced its antifungal } \\
\text { effects both in vivo and in vitro }\end{array}$ & [212] \\
\hline Solid lipid nanoparticles (SLN) & Terbinafine hydrochloride (TH) & C. albicans & Skin candidiasis & $\begin{array}{l}\text { SLN improved the stability and antifungal effects } \\
\text { of TH }\end{array}$ & [213] \\
\hline Solid lipid nanoparticles (SLN) & $\begin{array}{l}\text { Clotrimazole (CLZ) and } \\
\text { alphalipolic acid (ALA) }\end{array}$ & C. albicans & Anti-fungal growth & $\begin{array}{l}\text { SLN prolonged drug release without any burst } \\
\text { effect and facilitated antifungal effects in } \\
\text { animal model }\end{array}$ & [214] \\
\hline Solid lipid nanoparticles (SLN) & Natamycin & C. albicans, A. fumigatus & Fungal keratitis & $\begin{array}{l}\text { SLN sustained drug release and increased corneal } \\
\text { penetration. SLN-natamycin increased antifungal } \\
\text { activity without cytotoxic effects on corneal tissues }\end{array}$ & [215] \\
\hline $\begin{array}{l}\text { Nanostructured lipid } \\
\text { carriers (NLC) }\end{array}$ & Voriconazole & C. albicans & Anti-candidal hyphae formation & $\begin{array}{l}\text { NLC sustained drug release, inhibited hyphae } \\
\text { formation, and improved antifungal activities } \\
\text { in vitro }\end{array}$ & [216] \\
\hline $\begin{array}{l}\text { Nanostructured lipid } \\
\text { carriers (NLC) }\end{array}$ & Fluconazole & $\begin{array}{l}\text { Fluconazole-resistant strains of } \\
\text { C. albicans, C. glabrata, } \\
\text { C. parapsilosis }\end{array}$ & Anti-fungal growth & $\begin{array}{l}\text { NLC sustained drug release and improved } \\
\text { fungicidal activities }\end{array}$ & [217] \\
\hline
\end{tabular}


Table 6. Cont.

\begin{tabular}{|c|c|c|c|c|c|}
\hline Nanosystems & Active Antifungal Agents & Pathogens & Target Diseases & Antifungal Mechanisms and Outcomes & References \\
\hline $\begin{array}{l}\text { Nanostructured lipid carriers } \\
\text { (NLC) incorporated with } \\
\text { poloxamer P407 }\end{array}$ & Clotrimazole & Candida albicans & Anti-fungal growth & $\begin{array}{l}\text { NLC-P407 provided an optimized drug delivery } \\
\text { system with suitable viscosity for mucosal } \\
\text { application and four fold more antifungal activities } \\
\text { than Fungizone }{ }^{\mathrm{TM}} \text { (commercial antifungal drug) } \\
\text { against Candida albicans }\end{array}$ & [218] \\
\hline $\begin{array}{l}\text { Nanostructured lipid } \\
\text { carriers (NLC) }\end{array}$ & Miconazole & Candida albicans & Oral candidiasis & $\begin{array}{l}\text { NLC enhanced drug release, improved local } \\
\text { delivery of miconazole to the oral mucosa and } \\
\text { improved antifungal effects than miconazole alone }\end{array}$ & [219] \\
\hline $\begin{array}{l}\text { Nanostructured lipid } \\
\text { carriers (NLC) }\end{array}$ & Ketoconazole & C. neoformans & $\begin{array}{l}\text { Cryptococcal } \\
\text { meningoencephalitis }\end{array}$ & $\begin{array}{l}\text { NLC sustained drug release and improved } \\
\text { antifungal effects in mouse brain tissues }\end{array}$ & [221] \\
\hline $\begin{array}{l}\text { Nanostructured lipid carriers } \\
\text { (NLC) with Mediterranean } \\
\text { essential oils }\end{array}$ & Clotrimazole & $\begin{array}{l}\text { Candida albicans, C. krusei, } \\
\text { C. parapsilosis }\end{array}$ & Skin candidiasis & $\begin{array}{l}\text { NLC contained Mediterranean essential oils and } \\
\text { enhanced membrane permeabilization and } \\
\text { antifungal effects for treating topical candidiasis }\end{array}$ & {$[222]$} \\
\hline Lipid nanocapsules (LNC) & $\begin{array}{l}\text { Amiodarone (AMD) and/or } \\
\text { fluconazole (FLU) }\end{array}$ & C. neoformans & Anti-fungal growth & $\begin{array}{l}\text { LNC displayed better antifungal effects, whether it } \\
\text { was encapsulated with AMD, FLU, or AMD+FLU, } \\
\text { than single usage of these two drugs in cryptococcal } \\
\text { infected mice }\end{array}$ & [224] \\
\hline
\end{tabular}


Fungal infections are treated using AmB, the "gold standard" among polyene-based antifungal drugs. Because it is relatively hydrophobic, conventional administration relies on intravenous administration. However, it is significantly nephrotoxic and is associated with infusion-related reactions (up to 53\% of patients experience renal dysfunction) [225]. The AmB-liposome conjugates AmBisome ${ }^{\circledR}$ (a liposomal amphotericin) and Abelcet (an AmB-lipid complex; The Liposome Co., Princeton, NJ, USA) were developed as alternatives to AmB deoxycholate injections. Both are successful commercial nanoformulations of this antifungal drug. Liposomal AmB agents were developed to overcome the severe side effects and nephrotoxicity of AmB [226], and AmB lipid complexes have been developed over decades. Amphotec, an AmB colloidal dispersion system, was also developed. It offers lower renal toxicity and lower mortality according to a case study of 174 patients with invasive aspergillosis [196]. In another case study of 556 patients with various invasive fungal infections, Albecet showed anti-aspergillosis effects with moderately compromised nephrotoxicity compared to AmB [197]. Albecet appears to be better at treating filamentous fungal infections (Aspergillus) than yeast infections (Candida, Cryptococcus).

AmBisome ${ }^{\circledR}$ provides much greater antifungal effects against Candida [227]. Aside from being a liposome-based treatment for Candida, this nanosystem has been used to optimize Cryptococcus treatment strategies, although the literature is limited. Fu et al. firstly selected a fluorescent polypyridyl ruthenium complex, RC-7, with significantly lower minimum inhibitory and minimum fungicidal concentrations than fluconazole. It was loaded into brain-targeting nano-liposome particles to form RDP-liposome (RDP is a peptide derived from rabies virus glycoproteins). As a result, the fluconazole loaded RC-7 liposome nanoparticles could be guided through the BBB and accumulate in the brain. Remarkably, RDP-liposome prolonged the survival of meningoencephalitis-bearing mice [198]. Despite the many advantages of using liposomes for delivering antifungal drugs, their disadvantages cannot be overlooked. Liposome nanoparticles are soluble, they have short half-lives, and they oxidate and hydrolyze phospholipids [121].

Nanoemulsions (NEs) are dispersed systems of two immiscible liquids (either oil-inwater or water-in-oil) that are stabilized with an appropriate surfactant [228,229]. Particles of these NEs are typically smaller than $500 \mathrm{~nm}$, and they have good stability, rapid digestibility, controlled release, and good bioavailability. Moreover, their physicochemical characteristics allow the delivery of various drugs. The oily component of NEs varies (e.g., essential oils or triglycerides) based on their distinct physicochemical and biological properties, and the water layer can be one of various aqueous components. For instance, because essential oils have been shown to have antifungal effects, they can be used in the oily component $[230,231]$.

One NE containing essential oil from Pelargonium graveolens displayed anti-candida activity. Candida albicans and C. krusey showed less biofilm formation using this NE compared to the free essential oil [199]. Ocimum basilicum essential oil loaded in an NE showed augmented activity against C. albicans and C. tropicalis [231]. Two additional natural essential oils from Pogostemon heyneanus and Eucalyptus globulus were isolated and loaded into NEs, resulting in excellent inhibitory effects on both yeast growth and biofilm formation [200,201].

Even when plant-isolated essential oils are used, NEs can provide ideal delivery agents for known antifungal drugs. A nystatin-loaded NE has been tested against C. albicans for the treatment of skin candidiasis. Results have shown improved pharmacokinetic release of nystatin with good sustainability in the skin and NE acts as an optimal agent for treating skin candidiasis [202,203]. Additionally, ketoconazole and clove oil loaded into an NE showed strong disturbance of Candida fungal cell membranes and a better ketoconazole release profile compared to ketoconazole alone [204].

Besides conventional NEs in antifungal applications, gelling agent and thioglycolic acid have been used as permeation enhancers to improve ketoconazole's effect on onychomycosis. The optimized NE is referred to as nanoemulgel [206]. Nanoemulgel displayed $77.54 \pm 2.88 \%$ transungual permeation values for ketoconazole through goat hooves in $24 \mathrm{~h}$, 
in contrast to conventional NEs without a permeation enhancer (transungual permeation values $=62.49 \pm 2.98 \%$ ). Thus, there is no doubt that ketoconazole loaded nanoemulgel shows a significant zone of inhibitionfor T. rubrum and C. albicans. Nanoemulgel also has good biosafety according to skin irritation and histopathology studies on rat skin.

To improve the antifungal activities against $C$. albicans and $A$. niger for topical delivery, AmB-loaded NE was fabricated using Capmul PG8 and lipid surfactants. AmB-loaded NE had zones of inhibition of $19.1 \pm 1.4$ and $22.6 \pm 2.0 \mathrm{~mm}$ against $A$. niger and C. albicans, respectively. Ex vitro experiments demonstrated that this nanosystem enhances AmB release and has the highest rate in penetrating the stratum corneum barrier compared to AmB drug solution and Fungisome ${ }^{\circledR}$ (Liposomal AmB, commercial drug) [205]. In another system, NE provided an optimized nanosystem for improving AmB's local antifungal effect without theoretical systemic absorption [232]. Drug-loaded NEs have been demonstrated to have great potential therapeutic roles for topical fungal infection, but their antifungal roles in the treatment of invasive fungal infections need further evaluation.

Solid lipid nanoparticles (SLNs) are similar to NEs, but the essential oil component is replaced by solid lipids to improve the control of drug release, increase system stability, and reduce toxicity [233]. They are colloidal systems of submicron size, ranging from 50 to $100 \mathrm{~nm}$ [234,235]. The concentration of the solid lipid component ranges from $1 \%$ to $30 \% w / w$, whereas that of the surfactants ranges from 0.5 to $5 \%$ [236]. Because the solid lipid core is lipophilic, several hydrophobic drugs can be packed into this nanosystem. Antifungal drugs such as miconazole, AmB, fluconazole, ketoconazole, and voriconazole have been carried by SLNs.

Nokhodchi et al. developed fluconazole-loaded SLNs and demonstrated its significant inhibition of fluconazole-resistant strains of Candida [207]. After measuring the antifungal activities, fluconazole was released dramatically from SLNs in the first $30 \mathrm{~min}$ followed by a sustained release over $24 \mathrm{~h}$. The $\mathrm{MIC}_{50}$ of fluconazole-loaded SLNs for fluconazole-resistant strains were evaluated $(2 \mu \mathrm{g} / \mathrm{mL}, 1 \mu \mathrm{g} / \mathrm{mL}$ and $2 \mu \mathrm{g} / \mathrm{mL}$ for fluconazole-resistant strains of Candida albicans, Candida parapsilosis and Candida glabrata, respectively) This nanosystem based drug delivery system for inhibiting Candida strains exhibited low susceptibility against the conventional formulation of fluconazole.

Miconazole is another common broad-spectrum drug used against various fungal species, but it has poor water solubility. The use of SLNs alleviates this problem. Thus, various approaches have been used to enhance the antifungal efficiency of miconazone, such as adding surfactants or incorporating lipid nanoparticles, including SLNs [208,237,238], the latter of which also improves biodegradability, biocompatibility, and protection of the incorporated drug from chemical degradation [239]. In cutaneous and vulvovaginal candidiasis, ketoconazole dispersed into SLNs showed anti-candida activity [209,210]. Voriconazole, another common anti-fungal drug, was loaded into SLNs, and two studies showed antimycotic activity against C. glabrata when administered ocularly [211,240].

Besides azole drugs, as the antifungal gold standard, AmB has also been utilized as an effective agent for incorporation into SLNs to ameliorate its poor oral bioavailability. Both in vivo and in vitro pharmacodynamic and pharmacokinetic studies show that AmB loaded into SLNs provides better bioavailability and lower nephrotoxicity, and the anticandida efficiency of AmB appeared to be potentiated [212,213,241]. To optimize cutaneous treatments, terbinafine hydrochloride was incorporated into SLNs, resulting in prolonged drug activity and a promising alternative for the treatment of cutaneous candidiasis [213].

Not only can SLNs incorporate single antifungal drugs, they can take on and deliver a combination of antifungal agents. A drug delivery system that simultaneously transports two or more drugs to a target site represents a promising strategy that can improve the therapeutic effectiveness of those drugs and overcome drug resistance. Clotrimazole and alphalipolic acid were loaded into SLN, and various effects were found, including reductions in reactive oxygen species and allergic responses. In vitro, the combination showed prolonged drug release without a burst effect. In total, the growth of 25 strains of C. albicans was inhibited by this dual-drug delivery system. This study demonstrated that 
the antifungal effect of clotrimazole and the protective effect of alphalipolic acid could be combined using this optimized strategy for the treatment of candidiasis [214].

Finally, SLCs have been studied as a means of delivering natamycin with improved therapeutic effects against fungal keratitis [215]. This lipid-based drug delivery system showed sustained natamycin release and better corneal penetration compared to the drug alone. The SLCs significantly improved the antifungal effectiveness of natamycin against clinical isolates of $A$. fumigatus and $C$. albicans without cytotoxic effects on corneal tissues. With this evidence, the properties of SLNs render them the ability to significantly increase the bioavailability of antifungal agents while alleviating their side effects. Such SLN nanosystems are favorable for the treatment of cutaneous, oral, ocular, and vaginal fungal infections.

A nanostructured lipid nanocarrier (NLC) is a nanoscale colloidal system that has a hydrophobic nucleus dispersed in an aqueous membrane and is stabilized by a surfactant. It is considered an improvement over SLNs, although the manufacturing methods are similar $[242,243]$. The attractive properties of a synergic NLC system include nanoparticle size $(<100 \mathrm{~nm})$, broad size distribution, long-term stability, and low cytotoxicity to human cell lines (HaCaT and A431). The hydrophobic nucleus gives an NLC better biocompatibility and a larger drug payload compared to the solid lipids in SLNs. Moreover, substitution of the nucleus can improve drug release properties and the incidence of drug expulsion during development and storage $[236,244,245]$. Thus, broad-spectrum drugs carried by NLCs have applications in the treatment of fungal infections.

Several azole drugs with poor water solubility (voriconazole, clotrimazole, miconazole, fluconazole, and sertaconazole) have been incorporated into NLCs and used to treat fungal infections. One study indicated that voriconazole loaded onto NLCs significantly alleviated biofilm formation and fungal growth of C. albicans. This shows the critical role of NLCs in facilitating the inhibition effects of voriconazole against yeast-hyphae switching, a known critical virulence characteristic of the Candida species [216].

In another study, fluconazole-loaded NLCs were prepared using probe ultrasonication. The particles were approximately $126 \mathrm{~nm}$ in diameter and provided sustained drug release over $24 \mathrm{~h}$, resulting in a significant decrease in minimum inhibitory concentration for all Candida species. In particular, isolates of $C$. albicans were more susceptible to fluconazoleloaded NLCs than C. glabrata or C. parapsilosis [217].

To optimize the treatment of vaginal fungal infections, clotrimazole was dispersed into NLCs, improving its anti-fungal effects by about four times compared to commercial Fungizone $^{\mathrm{TM}}$ [218]. The NLCs produced by ultrasonication were viscosized by the addition of poloxamer P407 gel to obtain a clotrimazole-NLC-gel nanosystem. The most significant advantage of this system is its thermogelling property, by which the temperature of vaginal fluids is increased by the clotrimazole-NLC-gel. This facilitates the ability of clotrimazole to pass through the vaginal mucosa, resulting in improved antifungal effectiveness in the treatment of vaginal candidiasis.

To optimize treatments of oral fungal infections, miconazole has been used as the loaded drug, and this NLC-based hydrogel system controlled the release of miconazole [219]. The encapsulation of miconazole into NLCs improved its antifungal activity against $C$. albicans, giving this nanosystem the ability to obtain the same therapeutic effect with a 17-fold lower dose than a commercial oral gel formulation.

The therapeutic effects of itraconazole against dermal candidiasis have also improved with the use of NLCs [220]. Itraconazole-loaded NLCs decreased trans-epidermal water loss, an index of cutaneous barrier function, in intact skin and tissues damaged by a linear incision. This indicates that the NLCs improved the ability of itraconazole to localize within the skin. This NLC system was evaluated only on Galleria mellonella larvae, and in that setting, it showed significant antifungal effects against Sporothrix brasiliensis and C. albicans [220].

In another study, an NLC-based nose-to-brain drug delivery system was developed to overcome the poor ability of ketoconazole to penetrate the BBB. A large amount of 
fluorescent-labelled NLCs accumulated in the brain, and ketoconazole-loaded NLCs significantly inhibited the number of colony-forming units of $C$. neoformans in mouse brains [221]. The use of NLCs is not limited to delivering single antifungal drugs. A Mediterranean essential oil (Rosmarinus officinalis, Lavandula $\mathrm{x}$ intermedia, or Origanum vulgare) was loaded along with clorimazole in an NLC system, which increased the drug's effectiveness in an optimized treatment for Candida infections [222]. The essential oil enhanced the dermal permeability of the clotrimazole, possibly as a result of its excellent interaction with the skin, and the nanoparticles provided prolonged in vitro release of clotrimazole. The abilities of C. albicans, C. krusei, and C. parapsilosis to grow were significantly hampered, thus confirming that NLCs containing Mediterranean essential oils and clotrimazole represent a promising strategy for enhancing drug effectiveness against topical candidiasis.

The antifungal gold standard drug, AmB, has been used for many years. To optimize its effectiveness in the treatment of ocular fungal infections, AmB was loaded into a polyethylene glycol PEGylated NLC system using a high-pressure homogenization technique. The molecular weight of the PEG was varied to find the one that provided the best stability. When the NLC was PEGylated with 2K PEG, the system remained stable for at least 4 weeks at both $4{ }^{\circ} \mathrm{C}$ and $25^{\circ} \mathrm{C}$. In vitro, this system provided excellent antifungal activity against $C$. albicans and A. fumigatus. Compared to commercially available AmB formulations such as Fungizone ${ }^{\mathrm{TM}}$ and AmBisome ${ }^{\circledR}$, it showed significantly better antifungal activity, and compared to AmB alone, it showed lower cytotoxicity.

This structure facilitated the ocular bio-distribution of $\mathrm{AmB}$ when applied topically in animal experiments. The fabricated NLC system has an excellent ability to sustain antifungal agents, control drug release, and reduce Candida activity in ocular regions in animals. This optimized method can provide an innovative strategy for treating various fungal infections.

Compared to SLNs, most NLC-based drug delivery systems can be used to combat invasive and systemic fungal infections as well as those of a topical nature. They can also restrict fungal biofilm formation. In summary, this nanosystem provides a promising method for optimizing current antifungal therapies, given their unique properties of high biocompatibility, optimized bioavailability, and varied routes of administration.

Lipid nanocapsules (LNCs) are lipid-based nanocarriers that have a relatively novel structure, given that they have recently been introduced (in the 2000s). They consist of a core containing medium-chain triglycerides that is stealth-coated with a relatively rigid phospholipid/ethoxylated surfactant capsule [246]. Unlike SLNs and NLCs, LNCs are prepared using a low-energy phase-inversion method. The nanocapsule is less than $100 \mathrm{~nm}$ in size and has a narrow size distribution. It has high interfacial stability and excellent stability with the payload $[247,248]$. Such nanosystems have been developed as an effective cancer drug delivery tool to be used via parenteral [249], topical [250], or oral routes of administration [251,252].

Promising outcomes have been achieved when using LNCs for the delivery of antifungal drugs by various routes of administration. To optimize the treatment of dermal candidiasis, itraconazole-loaded LNCs were compared to itraconazole-loaded NLCs. The lipid nanocapsules showed significantly better in vitro characteristics such as the polydispersity index, itraconazole release profile, and antifungal activity against $C$. albicans. When applied topically, the nanocapsules showed better dermal retention of itraconazole in excised human skin. They provided a critical therapy for the treatment of induced cutaneous candidiasis in rats while avoiding histopathological changes in the epidermal and dermal layers of the skin during a 14-day treatment.

The study showed that LNCs have superior physicochemical characteristics for permeating the skin and treating dermal candidiasis. Resistance is another major problem with azole treatments. To evaluate fluconazole resistance reversion in C. albicans, C. glabrata, C. krusei, and C. tropicalis isolates, LNCs with modified lipid cores were loaded with fluconazole. The LNCs provided advantages such as a reduced fluconazole dose and resistance reversion in all Candida isolates. This study provided a potential application for 
an azole-LNC nanosystem in the treatment of fungal infections caused by resistant isolates of Candida [223].

To treat cryptococcosis, LNCs have been evaluated for their anti-cryptococcal effects in murine models [224]. This novel study focused not only on the use of LNCs in the delivery of conventional azole drugs, but also on developing synergic drugs for treating cryptococcosis in mice. The target was a fungal calcium channel and a selected blocker, amiodarone, was used as an alternative therapy. Amiodarone is an antiarrhythmic drug that shows broad-spectrum antifungal effects and is effective against $C$. neoformans [253]. It can interrupt the calcium-calcineurin signaling pathway, significantly compromising cryptococcal virulence [254,255]. It has also been used to treat fluconazole-resistant fungi [256].

In a recent study, amiodarone and fluconazole were loaded singularly and in combination into LNCs. Each one showed antifungal effects when administered intranasally, but the LNCs improved the anti-cryptococcal effects for amiodarone only. Therefore, the LNC system is a critical strategy for improving drug loading that improves efficiency and optimizes conventional cryptococcosis treatments.

Hydrophobic agents such as AmB and azoles can be dispersed into any of the lipidbased nanosystems: SLNs, NLCs, and LNCs. All of these are used in attempts to circumvent adverse effects and improve bioavailability in the treatment of oral, ocular, vaginal, or dermal fungal infections. Moreover, synergic incorporation of antifungal agents with natural biomolecules, such as plant-isolated essential oils, allows lipid-based nanosystems to boost drug sustainability, prolong drug release, and improve antifungal effects [224]. Thus, these three lipid-based nanosystems provide promising methods for optimizing antifungal therapies. However, in vivo experiments must be evaluated further.

\section{Conclusions and Perspectives}

Fungal infections have become a global burden and cause significant mortality. Conventional antifungal drugs have unsatisfactory therapeutic benefits, severe side effects, or unfavorable physicochemical properties. Nanoparticle-based drug delivery systems provide alternative strategies for overcoming these limitations, providing favorable properties such as small size, biocompatibility, and low toxicity.

This review has summarized the applications of four different categories of nanoparticles in antifungal therapy, which possesses with distinct properties. The metallic nanoparticles display chemical stability, adjustable pore size, and potential antifungal activity by inhibiting fungal enzymes and inducing the production of reactive oxygen species. Currently, the antifungal effects of gold, silver, zinc oxide, and iron oxide are mainly studied among metallic nanoparticles. However, the cost of materials is a limitation for the large-scale applications of such nanosystems.

MSNs are highly biocompatible and display satisfactory chemical and thermal stability. Due to their excellent plasticity and large drug-loading capacity, MSNs are suitable for loading large amounts of antifungal agents for treating severe fungal infection. PNs are also commonly used nanomaterials in drug-delivery systems and have been developed over half a century. Synthetic or natural polymers endow PNs with great capability to improve target guiding via surface ligand assembly, and fabricated PNs have been used as effective delivery systems for antifungal agents for decades.

Lastly, lipid-based nanoparticles involve several variations: liposomes, NEs, SLNs, NLCs, and LNCs. Although lipids are the fundamental structural components of these nanoparticles, they have distinct properties for incorporating different antifungal agents with either hydrophobic or hydrophilic properties. Moreover, distinct lipid nanoparticles display different tissue-penetration efficiency for circumventing tissue barriers.

The purpose of developing novel delivery systems for antifungal therapies or antifungal agents is to find an effective, economical, and low-toxicity therapeutic strategy. Although these nanomaterials have distinct properties, they significantly enhance drug bioavailability and stability and display non-toxic biological characteristics that can improve the potency of antifungal drugs. Nevertheless, optimized and novel nanomaterials 
need to be elucidated with more animal experiments and clinical trials to evaluate their antifungal efficiency and undesirable side effects in complex environments.

Funding: This work was supported by the National Natural Science Foundation of China (31870140 to C.D.), the Fundamental Research Funds for Central Universities of China (N142005001 and N172002001 to C.D.), and Liaoning Revitalization Talents Program (XLYC1807001).

Conflicts of Interest: The authors declare no conflict of interest.

\section{References}

1. One Health: Fungal Pathogens of Humans, Animals, and Plants: Report on an American Academy of Microbiology Colloquium held in Washington, DC, on 18 October 2017; American Society for Microbiology: Washington, DC, USA, 2019. [CrossRef]

2. Brown, G.D.; Denning, D.W.; Gow, N.A.; Levitz, S.M.; Netea, M.G.; White, T.C. Hidden killers: Human fungal infections. Sci. Transl. Med. 2012, 4, 165rv113. [CrossRef] [PubMed]

3. Brown, G.D.; Denning, D.W.; Levitz, S.M. Tackling human fungal infections. Science 2012, 336, 647. [CrossRef]

4. Kohler, J.R.; Hube, B.; Puccia, R.; Casadevall, A.; Perfect, J.R. Fungi that Infect Humans. Microbiol. Spectr. 2017, 5, 813-843. [CrossRef]

5. Denning, D.W.; Kneale, M.; Sobel, J.D.; Rautemaa-Richardson, R. Global burden of recurrent vulvovaginal candidiasis: A systematic review. Lancet Infect. Dis. 2018, 18, e339-e347. [CrossRef]

6. Singh, M.; Paul, N.; Singh, S.; Nayak, G.R. Asthma and Fungus: Role in Allergic Bronchopulmonary Aspergillosis (ABPA) and Other Conditions. Indian J. Pediatr. 2018, 85, 899-904. [CrossRef]

7. Carevic, M.; Singh, A.; Rieber, N.; Eickmeier, O.; Griese, M.; Hector, A.; Hartl, D. CXCR4+ granulocytes reflect fungal cystic fibrosis lung disease. Eur. Respir. J. 2015, 46, 395-404. [CrossRef]

8. Chotirmall, S.H.; McElvaney, N.G. Fungi in the cystic fibrosis lung: Bystanders or pathogens? Int. J. Biochem. Cell Biol. 2014, 52, 161-173. [CrossRef]

9. Denning, D.W.; Chakrabarti, A. Pulmonary and sinus fungal diseases in non-immunocompromised patients. Lancet Infect. Dis. 2017, 17, e357-e366. [CrossRef]

10. Tyler, M.A.; Lam, K.; Marino, M.J.; Yao, W.C.; Schmale, I.; Citardi, M.J.; Luong, A.U. Revisiting the controversy: The role of fungi in chronic rhinosinusitis. Int. Forum Allergy Rhinol. 2021. [CrossRef] [PubMed]

11. McCarty, T.P.; Pappas, P.G. Invasive Candidiasis. Infect. Dis. Clin. N. Am. 2016, 30, 103-124. [CrossRef]

12. Pappas, P.G.; Rex, J.H.; Lee, J.; Hamill, R.J.; Larsen, R.A.; Powderly, W.; Kauffman, C.A.; Hyslop, N.; Mangino, J.E.; Chapman, S.; et al. A prospective observational study of candidemia: Epidemiology, therapy, and influences on mortality in hospitalized adult and pediatric patients. Clin. Infect. Dis. 2003, 37, 634-643. [CrossRef] [PubMed]

13. Kullberg, B.J.; Arendrup, M.C. Invasive Candidiasis. N. Engl. J. Med. 2015, 373, 1445-1456. [CrossRef] [PubMed]

14. Wisplinghoff, H.; Bischoff, T.; Tallent, S.M.; Seifert, H.; Wenzel, R.P.; Edmond, M.B. Nosocomial bloodstream infections in US hospitals: Analysis of 24,179 cases from a prospective nationwide surveillance study. Clin. Infect. Dis. 2004, 39, 309-317. [CrossRef]

15. Spivak, E.S.; Hanson, K.E. Candida auris: An Emerging Fungal Pathogen. J. Clin. Microbiol. 2018, 56, e01588-17. [CrossRef] [PubMed]

16. Chowdhary, A.; Sharma, C.; Meis, J.F. Candida auris: A rapidly emerging cause of hospital-acquired multidrug-resistant fungal infections globally. PLoS Pathog. 2017, 13, e1006290. [CrossRef] [PubMed]

17. Lockhart, S.R.; Etienne, K.A.; Vallabhaneni, S.; Farooqi, J.; Chowdhary, A.; Govender, N.P.; Colombo, A.L.; Calvo, B.; Cuomo, C.A.; Desjardins, C.A.; et al. Simultaneous Emergence of Multidrug-Resistant Candida auris on 3 Continents Confirmed by Whole-Genome Sequencing and Epidemiological Analyses. Clin. Infect. Dis. 2017, 64, 134-140. [CrossRef] [PubMed]

18. Clancy, C.J.; Nguyen, M.H. Emergence of Candida auris: An International Call to Arms. Clin. Infect. Dis. 2017, 64, 141-143. [CrossRef]

19. Chan, J.F.; Lau, S.K.; Yuen, K.Y.; Woo, P.C. Talaromyces (Penicillium) marneffei infection in non-HIV-infected patients. Emerg. Microbes Infect. 2016, 5, e19. [CrossRef]

20. Latge, J.P.; Chamilos, G. Aspergillus fumigatus and Aspergillosis in 2019. Clin. Microbiol. Rev. 2019, 33, e00140-18. [CrossRef]

21. Pappas, P.G. Invasive candidiasis. Infect. Dis. Clin. N. Am. 2006, 20, 485-506. [CrossRef]

22. Binder, U.; Maurer, E.; Lass-Florl, C. Mucormycosis-From the pathogens to the disease. Clin. Microbiol. Infect. 2014, 20, 60-66. [CrossRef]

23. Saha, D.C.; Goldman, D.L.; Shao, X.; Casadevall, A.; Husain, S.; Limaye, A.P.; Lyon, M.; Somani, J.; Pursell, K.; Pruett, T.L.; et al. Serologic evidence for reactivation of cryptococcosis in solid-organ transplant recipients. Clin. Vaccine Immunol. 2007, 14, 1550-1554. [CrossRef] [PubMed]

24. Springer, D.J.; Billmyre, R.B.; Filler, E.E.; Voelz, K.; Pursall, R.; Mieczkowski, P.A.; Larsen, R.A.; Dietrich, F.S.; May, R.C.; Filler, S.G.; et al. Cryptococcus gattii VGIII isolates causing infections in HIV/AIDS patients in Southern California: Identification of the local environmental source as arboreal. PLoS Pathog. 2014, 10, e1004285. [CrossRef] [PubMed] 
25. Litvintseva, A.P.; Carbone, I.; Rossouw, J.; Thakur, R.; Govender, N.P.; Mitchell, T.G. Evidence that the human pathogenic fungus Cryptococcus neoformans var. grubii may have evolved in Africa. PLoS ONE 2011, 6, e19688. [CrossRef]

26. Baddley, J.W.; Schain, D.C.; Gupte, A.A.; Lodhi, S.A.; Kayler, L.K.; Frade, J.P.; Lockhart, S.R.; Chiller, T.; Bynon, J.S., Jr.; Bower, W.A. Transmission of Cryptococcus neoformans by Organ Transplantation. Clin. Infect. Dis. 2011, 52, e94-e98. [CrossRef]

27. Garcia-Hermoso, D.; Janbon, G.; Dromer, F. Epidemiological evidence for dormant Cryptococcus neoformans infection. J. Clin. Microbiol. 1999, 37, 3204-3209. [CrossRef]

28. Stephen, C.; Lester, S.; Black, W.; Fyfe, M.; Raverty, S. Multispecies outbreak of cryptococcosis on southern Vancouver Island, British Columbia. Can. Vet. J. 2002, 43, 792-794. [PubMed]

29. Kidd, S.E.; Hagen, F.; Tscharke, R.L.; Huynh, M.; Bartlett, K.H.; Fyfe, M.; Macdougall, L.; Boekhout, T.; Kwon-Chung, K.J.; Meyer, W. A rare genotype of Cryptococcus gattii caused the cryptococcosis outbreak on Vancouver Island (British Columbia, Canada). Proc. Natl. Acad. Sci. USA 2004, 101, 17258-17263. [CrossRef]

30. Kidd, S.E.; Guo, H.; Bartlett, K.H.; Xu, J.; Kronstad, J.W. Comparative gene genealogies indicate that two clonal lineages of Cryptococcus gattii in British Columbia resemble strains from other geographical areas. Eukaryot Cell 2005, 4, 1629-1638. [CrossRef]

31. Byrnes, E.J., 3rd; Bildfell, R.J.; Dearing, P.L.; Valentine, B.A.; Heitman, J. Cryptococcus gattii with bimorphic colony types in a dog in western Oregon: Additional evidence for expansion of the Vancouver Island outbreak. J. Vet. Diagn. Invest. 2009, 21, 133-136. [CrossRef]

32. Byrnes, E.J., 3rd; Bildfell, R.J.; Frank, S.A.; Mitchell, T.G.; Marr, K.A.; Heitman, J. Molecular evidence that the range of the Vancouver Island outbreak of Cryptococcus gattii infection has expanded into the Pacific Northwest in the United States. J. Infect. Dis. 2009, 199, 1081-1086. [CrossRef]

33. Byrnes, E.J.; Heitman, J. Cryptococcus gattii outbreak expands into the Northwestern United States with fatal consequences. F1000 Biol. Rep. 2009, 1, 62. [CrossRef]

34. Byrnes, E.J., 3rd; Li, W.; Lewit, Y.; Perfect, J.R.; Carter, D.A.; Cox, G.M.; Heitman, J. First reported case of Cryptococcus gattii in the Southeastern USA: Implications for travel-associated acquisition of an emerging pathogen. PLoS ONE 2009, 4, e5851. [CrossRef]

35. Datta, K.; Bartlett, K.H.; Baer, R.; Byrnes, E.; Galanis, E.; Heitman, J.; Hoang, L.; Leslie, M.J.; MacDougall, L.; Magill, S.S.; et al. Spread of Cryptococcus gattii into Pacific Northwest region of the United States. Emerg. Infect. Dis. 2009, 15, 1185-1191. [CrossRef]

36. Engelthaler, D.M.; Casadevall, A. On the Emergence of Cryptococcus gattii in the Pacific Northwest: Ballast Tanks, Tsunamis, and Black Swans. mBio 2019, 10, e02193-19. [CrossRef] [PubMed]

37. Chowdhary, A.; Rhandhawa, H.S.; Prakash, A.; Meis, J.F. Environmental prevalence of Cryptococcus neoformans and Cryptococcus gattii in India: An update. Crit. Rev. Microbiol. 2012, 38, 1-16. [CrossRef] [PubMed]

38. Steenbergen, J.N.; Shuman, H.A.; Casadevall, A. Cryptococcus neoformans interactions with amoebae suggest an explanation for its virulence and intracellular pathogenic strategy in macrophages. Proc. Natl. Acad. Sci. USA 2001, 98, 15245-15250. [CrossRef] [PubMed]

39. Ma, H.; Croudace, J.E.; Lammas, D.A.; May, R.C. Expulsion of live pathogenic yeast by macrophages. Curr. Biol. 2006, 16, 2156-2160. [CrossRef]

40. Alvarez, M.; Casadevall, A. Phagosome extrusion and host-cell survival after Cryptococcus neoformans phagocytosis by macrophages. Curr. Biol. 2006, 16, 2161-2165. [CrossRef]

41. Bloom, A.L.M.; Jin, R.M.; Leipheimer, J.; Bard, J.E.; Yergeau, D.; Wohlfert, E.A.; Panepinto, J.C. Thermotolerance in the pathogen Cryptococcus neoformans is linked to antigen masking via mRNA decay-dependent reprogramming. Nat. Commun. 2019, 10, 4950. [CrossRef] [PubMed]

42. Wang, Y.; Casadevall, A. Decreased susceptibility of melanized Cryptococcus neoformans to UV light. Appl. Environ. Microbiol. 1994, 60, 3864-3866. [CrossRef] [PubMed]

43. May, R.C.; Stone, N.R.; Wiesner, D.L.; Bicanic, T.; Nielsen, K. Cryptococcus: From environmental saprophyte to global pathogen. Nat. Rev. Microbiol. 2016, 14, 106-117. [CrossRef] [PubMed]

44. Rajasingham, R.; Rhein, J.; Klammer, K.; Musubire, A.; Nabeta, H.; Akampurira, A.; Mossel, E.C.; Williams, D.A.; Boxrud, D.J.; Crabtree, M.B.; et al. Epidemiology of meningitis in an HIV-infected Ugandan cohort. Am. J. Trop. Med. Hyg. 2015, 92, 274-279. [CrossRef] [PubMed]

45. Jarvis, J.N.; Meintjes, G.; Williams, A.; Brown, Y.; Crede, T.; Harrison, T.S. Adult meningitis in a setting of high HIV and TB prevalence: Findings from 4961 suspected cases. BMC Infect. Dis. 2010, 10, 67. [CrossRef] [PubMed]

46. Honda, H.; Warren, D.K. Central nervous system infections: Meningitis and brain abscess. Infect. Dis. Clin. N. Am. 2009, 23, 609-623. [CrossRef]

47. Mortensen, K.L.; Johansen, H.K.; Fuursted, K.; Knudsen, J.D.; Gahrn-Hansen, B.; Jensen, R.H.; Howard, S.J.; Arendrup, M.C. A prospective survey of Aspergillus spp. in respiratory tract samples: Prevalence, clinical impact and antifungal susceptibility. Eur. J. Clin. Microbiol. Infect. Dis. 2011, 30, 1355-1363. [CrossRef]

48. Nguyen, L.D.; Viscogliosi, E.; Delhaes, L. The lung mycobiome: An emerging field of the human respiratory microbiome. Front. Microbiol. 2015, 6, 89. [CrossRef]

49. Maiz, L.; Vendrell, M.; Olveira, C.; Giron, R.; Nieto, R.; Martinez-Garcia, M.A. Prevalence and factors associated with isolation of Aspergillus and Candida from sputum in patients with non-cystic fibrosis bronchiectasis. Respiration 2015, 89, 396-403. [CrossRef] 
50. Pashley, C.H.; Fairs, A.; Morley, J.P.; Tailor, S.; Agbetile, J.; Bafadhel, M.; Brightling, C.E.; Wardlaw, A.J. Routine processing procedures for isolating filamentous fungi from respiratory sputum samples may underestimate fungal prevalence. Med. Mycol. 2012, 50, 433-438. [CrossRef]

51. Denning, D.W.; Park, S.; Lass-Florl, C.; Fraczek, M.G.; Kirwan, M.; Gore, R.; Smith, J.; Bueid, A.; Moore, C.B.; Bowyer, P.; et al. High-frequency triazole resistance found In nonculturable Aspergillus fumigatus from lungs of patients with chronic fungal disease. Clin. Infect. Dis. 2011, 52, 1123-1129. [CrossRef]

52. Perfect, J.R.; Cox, G.M.; Lee, J.Y.; Kauffman, C.A.; de Repentigny, L.; Chapman, S.W.; Morrison, V.A.; Pappas, P.; Hiemenz, J.W.; Stevens, D.A.; et al. The impact of culture isolation of Aspergillus species: A hospital-based survey of Aspergillosis. Clin. Infect. Dis. 2001, 33, 1824-1833. [CrossRef]

53. Abdel Hameed, A.A.; Yasser, I.H.; Khoder, I.M. Indoor air quality during renovation actions: A case study. J. Environ. Monit. 2004, 6, 740-744. [CrossRef]

54. Mahieu, L.M.; De Dooy, J.J.; Van Laer, F.A.; Jansens, H.; Ieven, M.M. A prospective study on factors influencing aspergillus spore load in the air during renovation works in a neonatal intensive care unit. J. Hosp. Infect. 2000, 45, 191-197. [CrossRef]

55. Pini, G.; Faggi, E.; Donato, R.; Sacco, C.; Fanci, R. Invasive pulmonary aspergillosis in neutropenic patients and the influence of hospital renovation. Mycoses 2008, 51, 117-122. [CrossRef]

56. Van de Veerdonk, F.L.; Gresnigt, M.S.; Romani, L.; Netea, M.G.; Latge, J.P. Aspergillus fumigatus morphology and dynamic host interactions. Nat. Rev. Microbiol. 2017, 15, 661-674. [CrossRef]

57. Gago, S.; Overton, N.L.D.; Ben-Ghazzi, N.; Novak-Frazer, L.; Read, N.D.; Denning, D.W.; Bowyer, P. Lung colonization by Aspergillus fumigatus is controlled by ZNF77. Nat. Commun. 2018, 9, 3835. [CrossRef] [PubMed]

58. Pouliot, M.; Jeanmart, S. Pan Assay Interference Compounds (PAINS) and Other Promiscuous Compounds in Antifungal Research. J. Med. Chem. 2016, 59, 497-503. [CrossRef] [PubMed]

59. Shapiro, R.S.; Robbins, N.; Cowen, L.E. Regulatory circuitry governing fungal development, drug resistance, and disease. Microbiol. Mol. Biol. Rev. 2011, 75, 213-267. [CrossRef] [PubMed]

60. Vincent, B.M.; Lancaster, A.K.; Scherz-Shouval, R.; Whitesell, L.; Lindquist, S. Fitness trade-offs restrict the evolution of resistance to amphotericin B. PLoS Biol. 2013, 11, e1001692. [CrossRef]

61. Revie, N.M.; Iyer, K.R.; Robbins, N.; Cowen, L.E. Antifungal drug resistance: Evolution, mechanisms and impact. Curr. Opin. Microbiol. 2018, 45, 70-76. [CrossRef]

62. O'Meara, T.R.; Alspaugh, J.A. The Cryptococcus neoformans capsule: A sword and a shield. Clin. Microbiol. Rev. 2012, 25, 387-408. [CrossRef] [PubMed]

63. Gow, N.A.R.; Latge, J.P.; Munro, C.A. The Fungal Cell Wall: Structure, Biosynthesis, and Function. Microbiol. Spectr. 2017, 5, 267-292. [CrossRef]

64. Bowman, S.M.; Free, S.J. The structure and synthesis of the fungal cell wall. Bioessays 2006, 28, 799-808. [CrossRef]

65. Latge, J.P.; Beauvais, A.; Chamilos, G. The Cell Wall of the Human Fungal Pathogen Aspergillus fumigatus: Biosynthesis, Organization, Immune Response, and Virulence. Annu. Rev. Microbiol. 2017, 71, 99-116. [CrossRef]

66. Douglas, L.M.; Konopka, J.B. Fungal membrane organization: The eisosome concept. Annu. Rev. Microbiol. 2014, 68, 377-393. [CrossRef]

67. Klemptner, R.L.; Sherwood, J.S.; Tugizimana, F.; Dubery, I.A.; Piater, L.A. Ergosterol, an orphan fungal microbe-associated molecular pattern (MAMP). Mol. Plant. Pathol. 2014, 15, 747-761. [CrossRef]

68. Sheehan, D.J.; Hitchcock, C.A.; Sibley, C.M. Current and emerging azole antifungal agents. Clin. Microbiol. Rev. 1999, 12, 40-79. [CrossRef] [PubMed]

69. Carrillo-Munoz, A.J.; Giusiano, G.; Ezkurra, P.A.; Quindos, G. Antifungal agents: Mode of action in yeast cells. Rev. Esp. Quimioter. 2006, 19, 130-139.

70. Dellenbach, P.; Thomas, J.L.; Guerin, V.; Ochsenbein, E.; Contet-Audonneau, N. Topical treatment of vaginal candidosis with sertaconazole and econazole sustained-release suppositories. Int. J. Gynaecol. Obstet. 2000, 71, S47-S52. [CrossRef]

71. Benfield, P.; Clissold, S.P. Sulconazole. A review of its antimicrobial activity and therapeutic use in superficial dermatomycoses. Drugs 1988, 35, 143-153. [CrossRef]

72. Clissold, S.P.; Heel, R.C. Tioconazole. A review of its antimicrobial activity and therapeutic use in superficial mycoses. Drugs 1986, 31, 29-51. [CrossRef]

73. Lake-Bakaar, G.; Scheuer, P.J.; Sherlock, S. Hepatic reactions associated with ketoconazole in the United Kingdom. Br. Med. J. Clin. Res. Ed. 1987, 294, 419-422. [CrossRef]

74. Stricker, B.H.; Blok, A.P.; Bronkhorst, F.B.; Van Parys, G.E.; Desmet, V.J. Ketoconazole-associated hepatic injury. A clinicopathological study of 55 cases. J. Hepatol. 1986, 3, 399-406. [CrossRef]

75. Pont, A.; Goldman, E.S.; Sugar, A.M.; Siiteri, P.K.; Stevens, D.A. Ketoconazole-induced increase in estradiol-testosterone ratio. Probable explanation for gynecomastia. Arch. Intern. Med. 1985, 145, 1429-1431. [CrossRef]

76. Ellepola, A.N.; Samaranayake, L.P. Oral candidal infections and antimycotics. Crit. Rev. Oral. Biol. Med. 2000, 11, 172-198. [CrossRef]

77. Munoz, P.; Moreno, S.; Berenguer, J.; Bernaldo de Quiros, J.C.; Bouza, E. Fluconazole-related hepatotoxicity in patients with acquired immunodeficiency syndrome. Arch. Intern. Med. 1991, 151, 1020-1021. [CrossRef] 
78. Gayam, V.; Khalid, M.; Dahal, S.; Garlapati, P.; Gill, A. Hyperacute liver injury following intravenous fluconazole: A rare case of dose-independent hepatotoxicity. J. Family Med. Prim. Care 2018, 7, 451-454. [CrossRef]

79. Moon, W.J.; Scheller, E.L.; Suneja, A.; Livermore, J.A.; Malani, A.N.; Moudgal, V.; Kerr, L.E.; Ferguson, E.; Vandenberg, D.M. Plasma fluoride level as a predictor of voriconazole-induced periostitis in patients with skeletal pain. Clin. Infect. Dis. 2014, 59, 1237-1245. [CrossRef] [PubMed]

80. Tarlock, K.; Johnson, D.; Cornell, C.; Parnell, S.; Meshinchi, S.; Baker, K.S.; Englund, J.A. Elevated fluoride levels and periostitis in pediatric hematopoietic stem cell transplant recipients receiving long-term voriconazole. Pediatr. Blood Cancer 2015, 62, 918-920. [CrossRef]

81. Elewski, B.E.; Rich, P.; Pollak, R.; Pariser, D.M.; Watanabe, S.; Senda, H.; Ieda, C.; Smith, K.; Pillai, R.; Ramakrishna, T.; et al. Efinaconazole $10 \%$ solution in the treatment of toenail onychomycosis: Two phase III multicenter, randomized, double-blind studies. J. Am. Acad. Dermatol. 2013, 68, 600-608. [CrossRef]

82. McCormack, P.L. Isavuconazonium: First global approval. Drugs 2015, 75, 817-822. [CrossRef] [PubMed]

83. Young, G.A.; Bosly, A.; Gibbs, D.L.; Durrant, S. A double-blind comparison of fluconazole and nystatin in the prevention of candidiasis in patients with leukaemia. Antifungal Prophylaxis Study Group. Eur. J. Cancer 1999, 35, 1208-1213. [CrossRef]

84. Lalitha, P.; Vijaykumar, R.; Prajna, N.V.; Fothergill, A.W. In vitro natamycin susceptibility of ocular isolates of Fusarium and Aspergillus species: Comparison of commercially formulated natamycin eye drops to pharmaceutical-grade powder. J. Clin. Microbiol. 2008, 46, 3477-3478. [CrossRef]

85. Te Welscher, Y.M.; van Leeuwen, M.R.; de Kruijff, B.; Dijksterhuis, J.; Breukink, E. Polyene antibiotic that inhibits membrane transport proteins. Proc. Natl. Acad. Sci. USA 2012, 109, 11156-11159. [CrossRef] [PubMed]

86. Muller, G.G.; Kara-Jose, N.; de Castro, R.S. Antifungals in eye infections: Drugs and routes of administration. Rev. Bras. Oftalmol. 2013, 72, 132-141.

87. De la Torre, P.; Meyer, D.K.; Reboli, A.C. Anidulafungin: A novel echinocandin for candida infections. Future Microbiol. 2008, 3, 593-601. [CrossRef] [PubMed]

88. Vazquez, J.A.; Sobel, J.D. Anidulafungin: A novel echinocandin. Clin. Infect. Dis. 2006, 43, 215-222. [CrossRef]

89. Keating, G.M.; Figgitt, D.P. Caspofungin-A review of its use in oesophageal candidiasis, invasive candidiasis and invasive aspergillosis. Drugs 2003, 63, 2235-2263. [CrossRef]

90. Kofla, G.; Ruhnke, M. Pharmacology and metabolism of anidulafungin, caspofungin and micafungin in the treatment of invasive candidosis: Review of the literature. Eur. J. Med. Res. 2011, 16, 159-166. [CrossRef] [PubMed]

91. Singal, A. Butenafine and superficial mycoses: Current status. Expert. Opin. Drug. Metab. Toxicol. 2008, 4, 999-1005. [CrossRef]

92. Gupta, A.K.; Stec, N.; Summerbell, R.C.; Shear, N.H.; Piguet, V.; Tosti, A.; Piraccini, B.M. Onychomycosis: A review. J. Eur. Acad. Dermatol. Venereol. 2020, 34, 1972-1990. [CrossRef]

93. Lipner, S.R.; Scher, R.K. Onychomycosis: Treatment and prevention of recurrence. J. Am. Acad. Dermatol. 2019, 80, 853-867. [CrossRef] [PubMed]

94. Monk, J.P.; Brogden, R.N. Naftifine. A review of its antimicrobial activity and therapeutic use in superficial dermatomycoses. Drugs 1991, 42, 659-672. [CrossRef] [PubMed]

95. Matsumori, N.; Sawada, Y.; Murata, M. Mycosamine orientation of amphotericin B controlling interaction with ergosterol: Sterol-dependent activity of conformation-restricted derivatives with an amino-carbonyl bridge. J. Am. Chem. Soc. 2005, 127, 10667-10675. [CrossRef] [PubMed]

96. Bruheim, P.; Borgos, S.E.; Tsan, P.; Sletta, H.; Ellingsen, T.E.; Lancelin, J.M.; Zotchev, S.B. Chemical diversity of polyene macrolides produced by Streptomyces noursei ATCC 11455 and recombinant strain ERD44 with genetically altered polyketide synthase NysC. Antimicrob. Agents Chemother. 2004, 48, 4120-4129. [CrossRef]

97. Anderson, T.M.; Clay, M.C.; Cioffi, A.G.; Diaz, K.A.; Hisao, G.S.; Tuttle, M.D.; Nieuwkoop, A.J.; Comellas, G.; Maryum, N.; Wang, S.; et al. Amphotericin forms an extramembranous and fungicidal sterol sponge. Nat. Chem. Biol. 2014, 10, 400-406. [CrossRef] [PubMed]

98. Denning, D.W. Echinocandin antifungal drugs. Lancet 2003, 362, 1142-1151. [CrossRef]

99. Simitsopoulou, M.; Peshkova, P.; Tasina, E.; Katragkou, A.; Kyrpitzi, D.; Velegraki, A.; Walsh, T.J.; Roilides, E. Species-specific and drug-specific differences in susceptibility of Candida biofilms to echinocandins: Characterization of less common bloodstream isolates. Antimicrob. Agents Chemother. 2013, 57, 2562-2570. [CrossRef]

100. Ryder, N.S. Squalene epoxidase as a target for the allylamines. Biochem. Soc. Trans. 1991, 19, 774-777. [CrossRef]

101. Mohr, J.; Johnson, M.; Cooper, T.; Lewis, J.S.; Ostrosky-Zeichner, L. Current Options in Antifungal Pharmacotherapy. Pharmacother. Pharmacotherapy 2008, 28, 614-645. [CrossRef]

102. Mohd-Assaad, N.; McDonald, B.A.; Croll, D. Multilocus resistance evolution to azole fungicides in fungal plant pathogen populations. Mol. Ecol. 2016, 25, 6124-6142. [CrossRef] [PubMed]

103. Roemer, T.; Krysan, D.J. Antifungal drug development: Challenges, unmet clinical needs, and new approaches. Cold Spring Harb. Perspect. Med. 2014, 4, 4148-4153. [CrossRef] [PubMed]

104. Chandrasekar, P. Management of invasive fungal infections: A role for polyenes. J. Antimicrob. Chemother. 2011, 66, 457-465. [CrossRef] [PubMed]

105. Crawford, F.; Hollis, S. Topical treatments for fungal infections of the skin and nails of the foot. Cochrane Database Syst Rev. 2007, 3, CD001434. [CrossRef] 
106. Reboutier, D.; Piednoël, M.; Boisnard, S.; Conti, A.; Chevalier, V.; Florent, M.; Gibot-Leclerc, S.; Da Silva, B.; Chastin, C.; Fallague, K.; et al. Combination of different molecular mechanisms leading to fluconazole resistance in a Candida lusitaniae clinical isolate. Diagn. Microbiol. Infect. Dis. 2009, 63, 188-193. [CrossRef]

107. Florent, M.; Noël, T.; Ruprich-Robert, G.; Da Silva, B.; Fitton-Ouhabi, V.; Chastin, C.; Papon, N.; Chapeland-Leclerc, F. Nonsense and missense mutations in FCY2 and FCY1 genes are responsible for flucytosine resistance and flucytosine-fluconazole crossresistance in clinical isolates of Candida lusitaniae. Antimicrob. Agents Chemother. 2009, 53, 2982-2990. [CrossRef]

108. Vermes, A.; Guchelaar, H.J.; Dankert, J. Flucytosine: A review of its pharmacology, clinical indications, pharmacokinetics, toxicity and drug interactions. J. Antimicrob. Chemother. 2000, 46, 171-179. [CrossRef]

109. Hope, W.W.; Tabernero, L.; Denning, D.W.; Anderson, M.J. Molecular mechanisms of primary resistance to flucytosine in Candida albicans. Antimicrob. Agents Chemother. 2004, 48, 4377-4386. [CrossRef]

110. Chen, S.C.; Meyer, W.; Sorrell, T.C. Cryptococcus gattii infections. Clin. Microbiol. Rev. 2014, 27, 980-1024. [CrossRef] [PubMed]

111. Felton, T.; Troke, P.F.; Hope, W.W. Tissue penetration of antifungal agents. Clin. Microbiol. Rev. 2014, 27, 68-88. [CrossRef]

112. Shahid, S.K. Newer patents in antimycotic therapy. Pharm. Pat. Anal. 2016, 5, 115-134. [CrossRef]

113. Vandeputte, P.; Ferrari, S.; Coste, A.T. Antifungal resistance and new strategies to control fungal infections. Int. J. Microbiol. 2012, 2012, 713687. [CrossRef]

114. Mohammadi, G.; Shakeri, A.; Fattahi, A.; Mohammadi, P.; Mikaeili, A.; Aliabadi, A.; Adibkia, K. Preparation, Physicochemical Characterization and Anti-fungal Evaluation of Nystatin-Loaded PLGA-Glucosamine Nanoparticles. Pharm. Res. 2017, 34, 301-309. [CrossRef] [PubMed]

115. Niemirowicz, K.; Durnas, B.; Tokajuk, G.; Gluszek, K.; Wilczewska, A.Z.; Misztalewska, I.; Mystkowska, J.; Michalak, G.; Sodo, A.; Watek, M.; et al. Magnetic nanoparticles as a drug delivery system that enhance fungicidal activity of polyene antibiotics. Nanomedicine 2016, 12, 2395-2404. [CrossRef] [PubMed]

116. Das, B.; Khan, M.I.; Jayabalan, R.; Behera, S.K.; Yun, S.I.; Tripathy, S.K.; Mishra, A. Understanding the Antifungal Mechanism of Ag@ZnO Core-shell Nanocomposites against Candida krusei. Sci. Rep. 2016, 6, 36403. [CrossRef] [PubMed]

117. Chidambaram, M.; Manavalan, R.; Kathiresan, K. Nanotherapeutics to overcome conventional cancer chemotherapy limitations. J. Pharm. Pharm. Sci. 2011, 14, 67-77. [CrossRef] [PubMed]

118. Farokhzad, O.C. Nanotechnology for drug delivery: The perfect partnership. Expert. Opin. Drug. Deliv. 2008, 5, 927-929. [CrossRef]

119. Peer, D.; Karp, J.M.; Hong, S.; Farokhzad, O.C.; Margalit, R.; Langer, R. Nanocarriers as an emerging platform for cancer therapy. Nat. Nanotechnol. 2007, 2, 751-760. [CrossRef]

120. Power, S.; Slattery, M.M.; Lee, M.J. Nanotechnology and its relationship to interventional radiology. Part II: Drug Delivery, Thermotherapy, and Vascular Intervention. Cardiovasc. Intervent. Radiol. 2011, 34, 676-690. [CrossRef]

121. Dos Santos Ramos, M.A.; Da Silva, P.B.; Sposito, L.; De Toledo, L.G.; Bonifacio, B.V.; Rodero, C.F.; Dos Santos, K.C.; Chorilli, M.; Bauab, T.M. Nanotechnology-based drug delivery systems for control of microbial biofilms: A review. Int. J. Nanomedicine. 2018, 13, 1179-1213. [CrossRef]

122. Ghosh, P.; Han, G.; De, M.; Kim, C.K.; Rotello, V.M. Gold nanoparticles in delivery applications. Adv. Drug Deliv. Rev. 2008, 60, 1307-1315. [CrossRef]

123. More, M.P.; Ganguly, P.R.; Pandey, A.P.; Dandekar, P.P.; Jain, R.D.; Patil, P.O.; Deshmukh, P.K. Development of surface engineered mesoporous alumina nanoparticles: Drug release aspects and cytotoxicity assessment. Iet. Nanobiotechnol. 2017, 11, 661-668. [CrossRef]

124. Mathur, M.; Devi, V.K. Potential of novel drug delivery systems in the management of topical candidiasis. J. Drug Target. 2017, 25, 685-703. [CrossRef] [PubMed]

125. Weir, E.; Lawlor, A.; Whelan, A.; Regan, F. The use of nanoparticles in anti-microbial materials and their characterization. Analyst 2008, 133, 835-845. [CrossRef]

126. Wani, I.A.; Ahmad, T.; Manzoor, N. Size and shape dependant antifungal activity of gold nanoparticles: A case study of Candida. Colloids Surf. B Biointerfaces 2013, 101, 162-170. [CrossRef]

127. Choi, H.; Lee, D.G. Lycopene induces apoptosis in Candida albicans through reactive oxygen species production and mitochondrial dysfunction. Biochimie 2015, 115, 108-115. [CrossRef]

128. Shaikh, S.; Nazam, N.; Rizvi, S.M.D.; Ahmad, K.; Baig, M.H.; Lee, E.J.; Choi, I. Mechanistic Insights into the Antimicrobial Actions of Metallic Nanoparticles and Their Implications for Multidrug Resistance. Int. J. Mol. Sci. 2019, 20, 2468. [CrossRef] [PubMed]

129. Jebali, A.; Hajjar, F.H.E.; Hekmatimoghaddam, S.; Kazemi, B.; De La Fuente, J.M.; Rashidi, M. Triangular gold nanoparticles conjugated with peptide ligands: A new class of inhibitor for Candida albicans secreted aspartyl proteinase. Biochem. Pharmacol. 2014, 90, 349-355. [CrossRef]

130. Rahimi, H.; Roudbarmohammadi, S.; Delavari, H.H.; Roudbary, M. Antifungal effects of indolicidin-conjugated gold nanoparticles against fluconazole-resistant strains of Candida albicans isolated from patients with burn infection. Int. J. Nanomed. 2019, 14, 5323-5338. [CrossRef] [PubMed]

131. Ahmad, T.; Wani, I.A.; Lone, I.H.; Ganguly, A.; Manzoor, N.; Ahmad, A.; Ahmed, J.; Al-Shihri, A.S. Antifungal activity of gold nanoparticles prepared by solvothermal method. Mater. Res. Bull. 2013, 48, 12-20. [CrossRef]

132. Baygar, T.; Sarac, N.; Ugur, A.; Karaca, I.R. Antimicrobial characteristics and biocompatibility of the surgical sutures coated with biosynthesized silver nanoparticles. Bioorg. Chem. 2019, 86, 254-258. [CrossRef] [PubMed] 
133. Xu, L.; Wang, Y.Y.; Huang, J.; Chen, C.Y.; Wang, Z.X.; Xie, H. Silver nanoparticles: Synthesis, medical applications and biosafety. Theranostics 2020, 10, 8996-9031. [CrossRef] [PubMed]

134. Ahmad, A.; Wei, Y.; Syed, F.; Tahir, K.; Taj, R.; Khan, A.U.; Hameed, M.U.; Yuan, Q. Amphotericin B-conjugated biogenic silver nanoparticles as an innovative strategy for fungal infections. Microb. Pathog. 2016, 99, 271-281. [CrossRef]

135. Al Aboody, M.S. Silver/silver chloride $(\mathrm{Ag} / \mathrm{AgCl})$ nanoparticles synthesized from Azadirachta indica lalex and its antibiofilm activity against fluconazole resistant Candida tropicalis. Artif. Cells Nanomed. Biotechnol. 2019, 47, 2107-2113. [CrossRef]

136. Selvaraj, M.; Pandurangan, P.; Ramasami, N.; Rajendran, S.B.; Sangilimuthu, S.N.; Perumal, P. Highly potential antifungal activity of quantum-sized silver nanoparticles against Candida albicans. Appl. Biochem. Biotechnol. 2014, 173, 55-66. [CrossRef]

137. Ronavari, A.; Igaz, N.; Gopisetty, M.K.; Szerencses, B.; Kovacs, D.; Papp, C.; Vagvolgyi, C.; Boros, I.M.; Konya, Z.; Kiricsi, M.; et al. Biosynthesized silver and gold nanoparticles are potent antimycotics against opportunistic pathogenic yeasts and dermatophytes. Int. J. Nanomed. 2018, 13, 695-703. [CrossRef]

138. Jesmin, R.; Chanda, A. Restricting mycotoxins without killing the producers: A new paradigm in nano-fungal interactions. Appl. Microbiol. Biotechnol. 2020, 104, 2803-2813. [CrossRef]

139. Khalil, N.M.; Abd El-Ghany, M.N.; Rodriguez-Couto, S. Antifungal and anti-mycotoxin efficacy of biogenic silver nanoparticles produced by Fusarium chlamydosporum and Penicillium chrysogenum at non-cytotoxic doses. Chemosphere 2019, 218, 477-486. [CrossRef] [PubMed]

140. Ammar, H.A.; El-Desouky, T.A. Green synthesis of nanosilver particles by Aspergillus terreus HA1N and Penicillium expansum HA2N and its antifungal activity against mycotoxigenic fungi. J. Appl. Microbiol. 2016, 121, 89-100. [CrossRef] [PubMed]

141. Sirelkhatim, A.; Mahmud, S.; Seeni, A.; Kaus, N.H.M.; Ann, L.C.; Bakhori, S.K.M.; Hasan, H.; Mohamad, D. Review on Zinc Oxide Nanoparticles: Antibacterial Activity and Toxicity Mechanism. Nanomicrob. Lett. 2015, 7, 219-242. [CrossRef]

142. Sun, Q.; Li, J.; Le, T. Zinc Oxide Nanoparticle as a Novel Class of Antifungal Agents: Current Advances and Future Perspectives. J. Agric. Food Chem. 2018, 66, 11209-11220. [CrossRef] [PubMed]

143. Singh, S. Zinc oxide nanoparticles impacts: Cytotoxicity, genotoxicity, developmental toxicity, and neurotoxicity. Toxicol. Mech. Methods 2019, 29, 300-311. [CrossRef]

144. Khan, M.F.; Hameedullah, M.; Ansari, A.H.; Ahmad, E.; Lohani, M.B.; Khan, R.H.; Alam, M.M.; Khan, W.; Husain, F.M.; Ahmad, I. Flower-shaped $\mathrm{ZnO}$ nanoparticles synthesized by a novel approach at near-room temperatures with antibacterial and antifungal properties. Int. J. Nanomed. 2014, 9, 853-864. [CrossRef] [PubMed]

145. Siddiqi, K.S.; Ur Rahman, A.; Tajuddin; Husen, A. Properties of Zinc Oxide Nanoparticles and Their Activity against Microbes. Nanoscale Res. Lett. 2018, 13, 141. [CrossRef] [PubMed]

146. Abedzadeh Hajar, A.; Dakhili, M.; Saghazadeh, M.; Aghaei, S.S.; Nazari, R. Synergistic Antifungal Effect of Fluconazole Combined with ZnO Nanoparticles against Candida albicans Strains from Vaginal Candidiasis. Med Lab. J. 2020, 14, 26-32. [CrossRef]

147. Hosseini, S.S.; Joshaghani, H.; Shokohi, T.; Ahmadi, A.; Mehrbakhsh, Z. Antifungal Activity of ZnO Nanoparticles and Nystatin and Downregulation of SAP1-3 Genes Expression in Fluconazole-Resistant Candida albicans Isolates from Vulvovaginal Candidiasis Infect. Drug Resist. 2020, 13, 385-394. [CrossRef]

148. Wu, W.; Wu, Z.; Yu, T.; Jiang, C.; Kim, W.S. Recent progress on magnetic iron oxide nanoparticles: Synthesis, surface functional strategies and biomedical applications. Sci. Technol. Adv. Mater. 2015, 16, 023501. [CrossRef]

149. Vangijzegem, T.; Stanicki, D.; Laurent, S. Magnetic iron oxide nanoparticles for drug delivery: Applications and characteristics. Expert. Opin. Drug Deliv. 2019, 16, 69-78. [CrossRef]

150. Chifiriuc, C.; Grumezescu, V.; Grumezescu, A.M.; Saviuc, C.; Lazar, V.; Andronescu, E. Hybrid magnetite nanoparticles/Rosmarinus officinalis essential oil nanobiosystem with antibiofilm activity. Nanoscale Res. Lett. 2012, 7, 209. [CrossRef] [PubMed]

151. Chifiriuc, M.C.; Grumezescu, A.M.; Andronescu, E.; Ficai, A.; Cotar, A.I.; Grumezescu, V.; Bezirtzoglou, E.; Lazar, V.; Radulescu, R. Water dispersible magnetite nanoparticles influence the efficacy of antibiotics against planktonic and biofilm embedded Enterococcus faecalis cells. Anaerobe 2013, 22, 14-19. [CrossRef]

152. Hu, S.; Gu, F.; Chen, M.; Wang, C.W.; Li, J.; Yang, J.; Wang, G.Y.; Zhou, Z.; Yang, Y. A novel method for identifying and distinguishing Cryptococcus neoformans and Cryptococcus gattii by surface-enhanced Raman scattering using positively charged silver nanoparticles. Sci. Rep. 2020, 10, 12480. [CrossRef]

153. Rodriguez-Torres, M.D.P.; Diaz-Torres, L.A.; Millan-Chiu, B.E.; Garcia-Contreras, R.; Hernandez-Padron, G.; Acosta-Torres, L.S. Antifungal and Cytotoxic Evaluation of Photochemically Synthesized Heparin-Coated Gold and Silver Nanoparticles. Molecules 2020, 25, 2849. [CrossRef] [PubMed]

154. Hosseini, S.S.; Ghaemi, E.; Noroozi, A.; Niknejad, F. Zinc Oxide Nanoparticles Inhibition of Initial Adhesion and ALS1 and ALS3 Gene Expression in Candida albicans Strains from Urinary Tract Infections. Mycopathologia 2019, 184, 261-271. [CrossRef]

155. Hoang Thi, T.T.; Cao, V.D.; Nguyen, T.N.Q.; Hoang, D.T.; Ngo, V.C.; Nguyen, D.H. Functionalized mesoporous silica nanoparticles and biomedical applications. Mater. Sci. Eng. C Mater. Biol. Appl. 2019, 99, 631-656. [CrossRef] [PubMed]

156. Asefa, T.; Tao, Z. Biocompatibility of mesoporous silica nanoparticles. Chem. Res. Toxicol. 2012, 25, 2265-2284. [CrossRef]

157. Frickenstein, A.N.; Hagood, J.M.; Britten, C.N.; Abbott, B.S.; McNally, M.W.; Vopat, C.A.; Patterson, E.G.; MacCuaig, W.M.; Jain, A.; Walters, K.B.; et al. Mesoporous Silica Nanoparticles: Properties and Strategies for Enhancing Clinical Effect. Pharmaceutics 2021, 13, 570. [CrossRef] [PubMed]

158. Manzano, M.; Vallet-Regi, M. Mesoporous Silica Nanoparticles for Drug Delivery. Adv. Funct. Mater. 2020, 30, 1902634. [CrossRef] 
159. Mendiratta, S.; Hussein, M.; Nasser, H.A.; Ali, A.A.A. Multidisciplinary Role of Mesoporous Silica Nanoparticles in Brain Regeneration and Cancers: From Crossing the Blood-Brain Barrier to Treatment. Part. Part. Syst. Char. 2019, 36, 1900195. [CrossRef]

160. Qiao, Z.A.; Zhang, L.; Guo, M.Y.; Liu, Y.L.; Huo, Q.S. Synthesis of Mesoporous Silica Nanoparticles via Controlled Hydrolysis and Condensation of Silicon Alkoxide. Chem. Mater. 2009, 21, 3823-3829. [CrossRef]

161. Mas, N.; Galiana, I.; Hurtado, S.; Mondragon, L.; Bernardos, A.; Sancenon, F.; Marcos, M.D.; Amoros, P.; Abril-Utrillas, N.; Martinez-Manez, R.; et al. Enhanced antifungal efficacy of tebuconazole using gated pH-driven mesoporous nanoparticles. Int. J. Nanomed. 2014, 9, 2597-2605. [CrossRef]

162. Montazeri, M.; Razzaghi-Abyaneh, M.; Nasrollahi, S.A.; Maibach, H.; Nafisi, S. Enhanced topical econazole antifungal efficacy by amine-functionalized silica nanoparticles. B Mater. Sci. 2019, 43, 13. [CrossRef]

163. Abdelbar, M.F.; Shams, R.S.; Morsy, O.M.; Hady, M.A.; Shoueir, K.; Abdelmonem, R. Highly ordered functionalized mesoporous silicate nanoparticles reinforced poly (lactic acid) gatekeeper surface for infection treatment. Int. J. Biol. Macromol. 2020, 156, 858-868. [CrossRef] [PubMed]

164. Diez-Orejas, R.; Casarrubios, L.; Feito, M.J.; Rojo, J.M.; Vallet-Regi, M.; Arcos, D.; Portoles, M.T. Effects of mesoporous SiO2-CaO nanospheres on the murine peritoneal macrophages/Candida albicans interface. Int. Immunopharmacol. 2021, 94, 107457. [CrossRef]

165. Quiros, J.; Gonzalo, S.; Jalvo, B.; Boltes, K.; Perdigon-Melon, J.A.; Rosal, R. Electrospun cellulose acetate composites containing supported metal nanoparticles for antifungal membranes. Sci. Total. Environ. 2016, 563-564, 912-920. [CrossRef] [PubMed]

166. Schaffazick, S.R.; Pohlmann, A.R.; Dalla-Costa, T.; Guterres, S.S. Freeze-drying polymeric colloidal suspensions: Nanocapsules, nanospheres and nanodispersion. A comparative study. Eur. J. Pharm. Biopharm. 2003, 56, 501-505. [CrossRef]

167. Crucho, C.I.C.; Barros, M.T. Polymeric nanoparticles: A study on the preparation variables and characterization methods. Mater. Sci. Eng. C Mater. Biol. Appl. 2017, 80, 771-784. [CrossRef]

168. Guterres, S.S.; Alves, M.P.; Pohlmann, A.R. Polymeric nanoparticles, nanospheres and nanocapsules, for cutaneous applications. Drug Target. Insights 2007, 2, 147-157. [CrossRef]

169. Kleine-Brueggeney, H.; Zorzi, G.K.; Fecker, T.; El Gueddari, N.E.; Moerschbacher, B.M.; Goycoolea, F.M. A rational approach towards the design of chitosan-based nanoparticles obtained by ionotropic gelation. Colloid Surf. B 2015, 135, 99-108. [CrossRef] [PubMed]

170. Farrag, Y.; Ide, W.; Montero, B.; Rico, M.; Rodriguez-Llamazares, S.; Barral, L.; Bouza, R. Preparation of starch nanoparticles loaded with quercetin using nanoprecipitation technique. Int. J. Biol. Macromol. 2018, 114, 426-433. [CrossRef]

171. Sutar, Y.B.; Telvekar, V.N. Chitosan based copolymer-drug conjugate and its protein targeted polyelectrolyte complex nanoparticles to enhance the efficiency and specificity of low potency anticancer agent. Mat. Sci. Eng. C Mater. 2018, 92, 393-406. [CrossRef]

172. Gharieh, A.; Khoee, S.; Mandavian, A.R. Emulsion and miniemulsion techniques in preparation of polymer nanoparticles with versatile characteristics. Adv. Colloid Interfac. 2019, 269, 152-186. [CrossRef]

173. Patra, J.K.; Das, G.; Fraceto, L.F.; Campos, E.V.R.; Rodriguez-Torres, M.D.P.; Acosta-Torres, L.S.; Diaz-Torres, L.A.; Grillo, R.; Swamy, M.K.; Sharma, S.; et al. Nano based drug delivery systems: Recent developments and future prospects. J. Nanobiotechnol. 2018, 16, 71. [CrossRef] [PubMed]

174. Khan, I.; Saeed, K.; Khan, I. Nanoparticles: Properties, applications and toxicities. Arab. J. Chem. 2019, 12, 908-931. [CrossRef]

175. Kamaly, N.; Xiao, Z.; Valencia, P.M.; Radovic-Moreno, A.F.; Farokhzad, O.C. Targeted polymeric therapeutic nanoparticles: Design, development and clinical translation. Chem. Soc. Rev. 2012, 41, 2971-3010. [CrossRef]

176. Sakima, V.T.; Barbugli, P.A.; Cerri, P.S.; Chorilli, M.; Carmello, J.C.; Pavarina, A.C.; Mima, E.G.D. Antimicrobial Photodynamic Therapy Mediated by Curcumin-Loaded Polymeric Nanoparticles in a Murine Model of Oral Candidiasis. Molecules 2018, 23, 2075. [CrossRef] [PubMed]

177. Gondim, B.L.C.; Castellano, L.R.C.; de Castro, R.D.; Machad, G.; Carlo, H.L.; Valenca, A.M.G.; de Carvalho, F.G. Effect of chitosan nanoparticles on the inhibition of Candida spp. biofilm on denture base surface. Arch. Oral Biol. 2018, 94, 99-107. [CrossRef] [PubMed]

178. Lucena, P.A.; Nascimento, T.L.; Gaeti, M.P.N.; de Avila, R.I.; Mendes, L.P.; Vieira, M.S.; Fabrini, D.; Amaral, A.C.; Lima, E.M. In Vivo Vaginal Fungal Load Reduction after Treatment with Itraconazole-Loaded Polycaprolactone-Nanoparticles. J. Biomed. Nanotechnol. 2018, 14, 1347-1358. [CrossRef] [PubMed]

179. Amaral, A.C.; Saavedra, P.H.V.; Souza, A.C.O.; de Melo, M.T.; Tedesco, A.C.; Morais, P.C.; Felipe, M.S.S.; Bocca, A.L. Miconazole loaded chitosan-based nanoparticles for local treatment of vulvovaginal candidiasis fungal infections. Colloid Surf. B 2019, 174, 409-415. [CrossRef]

180. Costa, A.F.; Araujo, D.E.; Cabral, M.S.; Brito, I.T.; Leite, L.B.D.; Pereira, M.; Amaral, A.C. Development, characterization, and in vitro-in vivo evaluation of polymeric nanoparticles containing miconazole and farnesol for treatment of vulvovaginal candidiasis. Med Mycol. 2019, 57, 52-62. [CrossRef]

181. Melo, C.M.; Cardoso, J.F.; Perassoli, F.B.; Neto, A.S.D.; Pinto, L.M.; Marques, M.B.D.; Mussel, W.D.; Magalhaes, J.T.; Moura, S.A.D.; Araujo, M.G.D.; et al. Amphotericin B-loaded Eudragit RL100 nanoparticles coated with hyaluronic acid for the treatment of vulvovaginal candidiasis. Carbohyd. Polym. 2020, 230, 115608. [CrossRef]

182. Carraro, T.C.M.M.; Altmeyer, C.; Khalil, N.M.; Mainardes, R.M. Assessment of in vitro antifungal efficacy and in vivo toxicity of Amphotericin B-loaded PLGA and PLGA-PEG blend nanoparticles. J. Mycol. Med. 2017, 27, 519-529. [CrossRef] [PubMed] 
183. Torres-Rego, M.; Glaucia-Silva, F.; Rocha Soares, K.S.; de Souza, L.; Damasceno, I.Z.; Santos-Silva, E.D.; Lacerda, A.F.; Chaves, G.M.; Silva-Junior, A.A.D.; Fernandes-Pedrosa, M.F. Biodegradable cross-linked chitosan nanoparticles improve anti-Candida and anti-biofilm activity of TistH, a peptide identified in the venom gland of the Tityus stigmurus scorpion. Mater. Sci. Eng. C Mater. Biol. Appl. 2019, 103, 109830. [CrossRef] [PubMed]

184. Xu, N.; Gu, J.; Zhu, Y.; Wen, H.; Ren, Q.; Chen, J. Efficacy of intravenous amphotericin B-polybutylcyanoacrylate nanoparticles against cryptococcal meningitis in mice. Int. J. Nanomed. 2011, 6, 905-913. [CrossRef] [PubMed]

185. Tang, Y.X.; Wu, S.; Lin, J.Q.; Cheng, L.T.; Zhou, J.; Xie, J.; Huang, K.X.; Wang, X.Y.; Yu, Y.; Chen, Z.B.; et al. Nanoparticles Targeted against Cryptococcal Pneumonia by Interactions between Chitosan and Its Peptide Ligand. Nano Lett. 2018, 18, 6207-6213. [CrossRef]

186. Roque, L.; Castro, P.; Molpeceres, J.; Viana, A.S.; Roberto, A.; Reis, C.; Rijo, P.; Tho, I.; Sarmento, B.; Reis, C. Bioadhesive polymeric nanoparticles as strategy to improve the treatment of yeast infections in oral cavity: In-vitro and ex-vivo studies. Eur. Polym. J. 2018, 104, 19-31. [CrossRef]

187. Calvo, N.L.; Sreekumar, S.; Svetaz, L.A.; Lamas, M.C.; Moerschbacher, B.M.; Leonardi, D. Design and Characterization of Chitosan Nanoformulations for the Delivery of Antifungal Agents. Int. J. Mol. Sci. 2019, 20, 3686. [CrossRef] [PubMed]

188. Daraee, H.; Etemadi, A.; Kouhi, M.; Alimirzalu, S.; Akbarzadeh, A. Application of liposomes in medicine and drug delivery. Artif. Cell Nanomed. B 2016, 44, 381-391. [CrossRef]

189. Luo, Y.L.; Liu, Z.B.; Zhang, X.Q.; Huang, J.; Yu, X.; Li, J.W.; Xiong, D.; Sun, X.D.; Zhong, Z.R. Effect of a controlled-release drug delivery system made of oleanolic acid formulated into multivesicular liposomes on hepatocellular carcinoma in vitro and in vivo. Int. J. Nanomed. 2016, 11, 3111-3129. [CrossRef]

190. Panahi, Y.; Farshbaf, M.; Mohammadhosseini, M.; Mirahadi, M.; Khalilov, R.; Saghfi, S.; Akbarzadeh, A. Recent advances on liposomal nanoparticles: Synthesis, characterization and biomedical applications. Artif. Cells Nanomed. Biotechnol. 2017, 45, 788-799. [CrossRef]

191. Chorilli, M.; Calixto, G.; Rimerio, T.C.; Scarpa, M.V. Caffeine Encapsulated in Small Unilamellar Liposomes: Characerization and In Vitro Release Profile. J. Disper. Sci. Technol. 2013, 34, 1465-1470. [CrossRef]

192. Deshpande, P.P.; Biswas, S.; Torchilin, V.P. Current trends in the use of liposomes for tumor targeting. Nanomedicine 2013, 8 , 1509-1528. [CrossRef] [PubMed]

193. Allen, T.M.; Cullis, P.R. Liposomal drug delivery systems: From concept to clinical applications. Adv. Drug Deliv. Rev. 2013, 65, 36-48. [CrossRef] [PubMed]

194. Zylberberg, C.; Matosevic, S. Pharmaceutical liposomal drug delivery: A review of new delivery systems and a look at the regulatory landscape. Drug Deliv. 2016, 23, 3319-3329. [CrossRef] [PubMed]

195. Abu Lila, A.S.; Ishida, T. Liposomal Delivery Systems: Design Optimization and Current Applications. Biol. Pharm. Bull. 2017, 40, 1-10. [CrossRef]

196. Bowden, R.; Chandrasekar, P.; White, M.H.; Li, X.; Pietrelli, L.; Gurwith, M.; van Burik, J.A.; Laverdiere, M.; Safrin, S.; Wingard, J.R. A double-blind, randomized, controlled trial of amphotericin B colloidal dispersion versus amphotericin B for treatment of invasive aspergillosis in immunocompromised patients. Clin. Infect. Dis. 2002, 35, 359-366. [CrossRef]

197. Walsh, T.J.; Hiemenz, J.W.; Seibel, N.L.; Perfect, J.R.; Horwith, G.; Lee, L.; Silber, J.L.; DiNubile, M.J.; Reboli, A.; Bow, E.; et al. Amphotericin B lipid complex for invasive fungal infections: Analysis of safety and efficacy in 556 cases. Clin. Infect. Dis. 1998, 26, 1383-1396. [CrossRef]

198. Wang, Q.H.; Fu, C.; Zhao, Z.Z.; Fu, A.L. Targeted Theranostic of Cryptococcal Encephalitis by a Novel Polypyridyl Ruthenium Complex. Mol. Pharmaceut. 2020, 17, 145-154. [CrossRef]

199. Giongo, J.L.; de Almeida Vaucher, R.; Fausto, V.P.; Quatrin, P.M.; Lopes, L.Q.S.; Santos, R.C.V.; Gundel, A.; Gomes, P.; Steppe, M. Anti-Candida activity assessment of Pelargonium graveolens oil free and nanoemulsion in biofilm formation in hospital medical supplies. Microb. Pathog. 2016, 100, 170-178. [CrossRef]

200. De Siqueira, L.B.D.; Matos, A.P.D.; Cardoso, V.D.; Villanova, J.C.O.; Guimaraes, B.D.L.R.; dos Santos, E.P.; Vermelho, A.B.; Santos-Oliveira, R.; Ricci, E. Clove oil nanoemulsion showed potent inhibitory effect against Candida spp. Nanotechnology 2019, 30, 425101. [CrossRef]

201. Adhavan, P.; Kaur, G.; Princy, A.; Murugan, R. Essential oil nanoemulsions of wild patchouli attenuate multi-drug resistant gram-positive, gram-negative and Candida albicans. Ind. Crop. Prod. 2017, 100, 106-116. [CrossRef]

202. Fernandez Campos, F.; Calpena Campmany, A.C.; Rodriguez Delgado, G.; Lopez Serrano, O.; Clares Naveros, B. Development and characterization of a novel nystatin-loaded nanoemulsion for the buccal treatment of candidosis: Ultrastructural effects and release studies. J. Pharm. Sci. 2012, 101, 3739-3752. [CrossRef]

203. Fernandez-Campos, F.; Clares Naveros, B.; Lopez Serrano, O.; Alonso Merino, C.; Calpena Campmany, A.C. Evaluation of novel nystatin nanoemulsion for skin candidosis infections. Mycoses 2013, 56, 70-81. [CrossRef]

204. De Campos, V.E.B.; Cerqueira-Coutinho, C.S.; Capella, F.N.C.; Soares, B.G.; Holandino, C.; Mansur, C.R.E. Development and In Vitro Assessment of Nanoemulsion for Delivery of Ketoconazole Against Candida albicans. J. Nanosci. Nanotechnol. 2017, 17, 4623-4630. [CrossRef] 
205. Hussain, A.; Singh, V.K.; Singh, O.P.; Shafaat, K.; Kumar, S.; Ahmad, F.J. Formulation and optimization of nanoemulsion using antifungal lipid and surfactant for accentuated topical delivery of Amphotericin B. Drug Deliv. 2016, 23, 3101-3110. [CrossRef] [PubMed]

206. Mahtab, A.; Anwar, M.; Mallick, N.; Naz, Z.; Jain, G.K.; Ahmad, F.J. Transungual Delivery of Ketoconazole Nanoemulgel for the Effective Management of Onychomycosis. AAPS PharmSciTech 2016, 17, 1477-1490. [CrossRef] [PubMed]

207. Moazeni, M.; Kelidari, H.R.; Saeedi, M.; Morteza-Semnani, K.; Nabili, M.; Gohar, A.A.; Akbari, J.; Lotfali, E.; Nokhodchi, A. Time to overcome fluconazole resistant Candida isolates: Solid lipid nanoparticles as a novel antifungal drug delivery system. Colloids Surf. B Biointerfaces 2016, 142, 400-407. [CrossRef]

208. Jain, S.; Jain, S.; Khare, P.; Gulbake, A.; Bansal, D.; Jain, S.K. Design and development of solid lipid nanoparticles for topical delivery of an anti-fungal agent. Drug Deliv. 2010, 17, 443-451. [CrossRef]

209. Ramasamy, T.; Khandasami, U.S.; Ruttala, H.; Shanmugam, S. Development of solid lipid nanoparticles enriched hydrogels for topical delivery of anti-fungal agent. Macromol. Res. 2012, 20, 682-692. [CrossRef]

210. Cassano, R.; Ferrarelli, T.; Mauro, M.V.; Cavalcanti, P.; Picci, N.; Trombino, S. Preparation, characterization and in vitro activities evaluation of solid lipid nanoparticles based on PEG-40 stearate for antifungal drugs vaginal delivery. Drug Deliv. 2016, 23, 1047-1056. [CrossRef] [PubMed]

211. Khare, A.; Singh, I.; Pawar, P.; Grover, K. Design and Evaluation of Voriconazole Loaded Solid Lipid Nanoparticles for Ophthalmic Application. J. Drug Deliv. 2016, 2016, 6590361. [CrossRef]

212. Chaudhari, M.B.; Desai, P.P.; Patel, P.A.; Patravale, V.B. Solid lipid nanoparticles of amphotericin B (AmbiOnp): In vitro and in vivo assessment towards safe and effective oral treatment module. Drug Deliv. Transl. Res. 2016, 6, 354-364. [CrossRef]

213. Vaghasiya, H.; Kumar, A.; Sawant, K. Development of solid lipid nanoparticles based controlled release system for topical delivery of terbinafine hydrochloride. Eur. J. Pharm. Sci. 2013, 49, 311-322. [CrossRef]

214. Carbone, C.; Fuochi, V.; Zielinska, A.; Musumeci, T.; Souto, E.B.; Bonaccorso, A.; Puglia, C.; Petronio Petronio, G.; Furneri, P.M. Dual-drugs delivery in solid lipid nanoparticles for the treatment of Candida albicans mycosis. Colloids Surf. B Biointerfaces 2020, 186, 110705. [CrossRef]

215. Khames, A.; Khaleel, M.A.; El-Badawy, M.F.; El-Nezhawy, A.O.H. Natamycin solid lipid nanoparticles-Sustained ocular delivery system of higher corneal penetration against deep fungal keratitis: Preparation and optimization. Int. J. Nanomed. 2019, 14, 2515-2531. [CrossRef] [PubMed]

216. Tian, B.; Yan, Q.; Wang, J.; Ding, C.; Sai, S. Enhanced antifungal activity of voriconazole-loaded nanostructured lipid carriers against Candida albicans with a dimorphic switching model. Int. J. Nanomed. 2017, 12, 7131-7141. [CrossRef] [PubMed]

217. Kelidari, H.R.; Moazeni, M.; Babaei, R.; Saeedi, M.; Akbari, J.; Parkoohi, P.I.; Nabili, M.; Gohar, A.A.; Morteza-Semnani, K.; Nokhodchi, A. Improved yeast delivery of fluconazole with a nanostructured lipid carrier system. Biomed. Pharmacother. 2017, 89, 83-88. [CrossRef]

218. Ravani, L.; Esposito, E.; Bories, C.; Moal, V.L.; Loiseau, P.M.; Djabourov, M.; Cortesi, R.; Bouchemal, K. Clotrimazole-loaded nanostructured lipid carrier hydrogels: Thermal analysis and in vitro studies. Int. J. Pharm. 2013, 454, 695-702. [CrossRef] [PubMed]

219. Mendes, A.I.; Silva, A.C.; Catita, J.A.; Cerqueira, F.; Gabriel, C.; Lopes, C.M. Miconazole-loaded nanostructured lipid carriers (NLC) for local delivery to the oral mucosa: Improving antifungal activity. Colloids Surf. B Biointerfaces 2013, 111, 755-763. [CrossRef]

220. Passos, J.S.; Martino, L.C.; Dartora, V.F.C.; Araujo, G.L.B.; Ishida, K.; Lopes, L.B. Development, skin targeting and antifungal efficacy of topical lipid nanoparticles containing itraconazole. Eur. J. Pharm. Sci. 2020, 149, 105296. [CrossRef]

221. Du, W.; Li, H.; Tian, B.; Sai, S.; Gao, Y.; Lan, T.; Meng, Y.; Ding, C. Development of nose-to-brain delivery of ketoconazole by nanostructured lipid carriers against cryptococcal meningoencephalitis in mice. Colloids Surf. B Biointerfaces 2019, 183, 110446. [CrossRef]

222. Carbone, C.; Teixeira, M.D.C.; Sousa, M.D.C.; Martins-Gomes, C.; Silva, A.M.; Souto, E.M.B.; Musumeci, T. Clotrimazole-Loaded Mediterranean Essential Oils NLC: A Synergic Treatment of Candida Skin Infections. Pharmaceutics 2019, 11, 231. [CrossRef]

223. Bianchin, M.D.; Borowicz, S.M.; Machado, G.D.M.; Pippie, B.; Guterres, S.S.; Pohlmann, A.R.; Fuentefria, A.M.; KulkampGuerreiro, I.C. Lipid core nanoparticles as a broad strategy to reverse fluconazole resistance in multiple Candida species. Colloid Surface B 2019, 175, 523-529. [CrossRef]

224. Oliveira, N.K.; Frank, L.A.; Squizani, E.D.; Reuwsaat, J.C.V.; Marques, B.M.; Motta, H.; Garcia, A.W.A.; Kinskovski, U.P.; Barcellos, V.A.; Schrank, A.; et al. New nanotechnological formulation based on amiodarone-loaded lipid core nanocapsules displays anticryptococcal effect. Eur. J. Pharm. Sci. 2021, 162, 105816. [CrossRef]

225. Wingard, J.R.; Kubilis, P.; Lee, L.; Yee, G.; White, M.; Walshe, L.; Bowden, R.; Anaissie, E.; Hiemenz, J.; Lister, J. Clinical significance of nephrotoxicity in patients treated with amphotericin B for suspected or proven aspergillosis. Clin. Infect. Dis. 1999, 29, 1402-1407. [CrossRef] [PubMed] 
226. Olson, J.A.; Adler-Moore, J.P.; Jensen, G.M.; Schwartz, J.; Dignani, M.C.; Proffitt, R.T. Comparison of the physicochemical, antifungal, and toxic properties of two liposomal amphotericin B products. Antimicrob. Agents Chemother. 2008, 52, 259-268. [CrossRef] [PubMed]

227. Hann, I.M.; Prentice, H.G. Lipid-based amphotericin B: A review of the last 10 years of use. Int. J. Antimicrob. Agents 2001, 17, 161-169. [CrossRef]

228. Mason, T.G.; Graves, S.M.; Wilking, J.N.; Lin, M.Y. Effective structure factor of osmotically deformed nanoemulsions. J. Phys. Chem. B 2006, 110, 22097-22102. [CrossRef] [PubMed]

229. Singh, Y.; Meher, J.G.; Raval, K.; Khan, F.A.; Chaurasia, M.; Jain, N.K.; Chourasia, M.K. Nanoemulsion: Concepts, development and applications in drug delivery. J. Control. Release 2017, 252, 28-49. [CrossRef]

230. Dos Santos, M.K.; Kreutz, T.; Danielli, L.J.; De Marchi, J.G.B.; Pippi, B.; Koester, L.S.; Fuentefria, A.M.; Limberger, R.P. A chitosan hydrogel-thickened nanoemulsion containing Pelargonium graveolens essential oil for treatment of vaginal candidiasis. J. Drug Deliv. Sci. Tecnol. 2020, 56, 101527. [CrossRef]

231. Gundel, S.D.; Velho, M.C.; Diefenthaler, M.K.; Favarin, F.R.; Copetti, P.M.; Fogaca, A.D.; Klein, B.; Wagner, R.; Gundel, A.; Sagrillo, M.R.; et al. Basil oil-nanoemulsions: Development, cytotoxicity and evaluation of antioxidant and antimicrobial potential. J. Drug Deliv. Sci. Technol. 2018, 46, 378-383. [CrossRef]

232. Sosa, L.; Clares, B.; Alvarado, H.L.; Bozal, N.; Domenech, O.; Calpena, A.C. Amphotericin B releasing topical nanoemulsion for the treatment of candidiasis and aspergillosis. Nanomedicine 2017, 13, 2303-2312. [CrossRef] [PubMed]

233. Martins, S.; Sarmento, B.; Ferreira, D.C.; Souto, E.B. Lipid-based colloidal carriers for peptide and protein delivery-Liposomes versus lipid nanoparticles. Int. J. Nanomed. 2007, 2, 595-607.

234. Battaglia, L.; Gallarate, M. Lipid nanoparticles: State of the art, new preparation methods and challenges in drug delivery. Expert Opin. Drug Deliv. 2012, 9, 497-508. [CrossRef]

235. Mishra, V.; Bansal, K.K.; Verma, A.; Yadav, N.; Thakur, S.; Sudhakar, K.; Rosenholm, J.M. Solid Lipid Nanoparticles: Emerging Colloidal Nano Drug Delivery Systems. Pharmaceutics 2018, 10, 191. [CrossRef] [PubMed]

236. Gordillo-Galeano, A.; Mora-Huertas, C.E. Solid lipid nanoparticles and nanostructured lipid carriers: A review emphasizing on particle structure and drug release. Eur. J. Pharm. Biopharm. 2018, 133, 285-308. [CrossRef]

237. Levy, M.Y.; Polacheck, I.; Barenholz, Y.; Benita, S. Efficacy evaluation of a novel submicron miconazole emulsion in a murine cryptococcosis model. Pharm. Res. 1995, 12, 223-230. [CrossRef]

238. Muller, R.H.; Shegokar, R.; Keck, C.M. 20 years of lipid nanoparticles (SLN and NLC): Present state of development and industrial applications. Curr. Drug Discov. Technol. 2011, 8, 207-227. [CrossRef]

239. Muller, R.H.; Mader, K.; Gohla, S. Solid lipid nanoparticles (SLN) for controlled drug delivery-A review of the state of the art. Eur. J. Pharm. Biopharm. 2000, 50, 161-177. [CrossRef]

240. Furedi, P.; Papay, Z.E.; Kovacs, K.; Kiss, B.D.; Ludanyi, K.; Antal, I.; Klebovich, I. Development and characterization of the voriconazole loaded lipid-based nanoparticles. J. Pharm. Biomed. Anal. 2017, 132, 184-189. [CrossRef]

241. Patel, P.A.; Patravale, V.B. AmbiOnp: Solid lipid nanoparticles of amphotericin B for oral administration. J. Biomed. Nanotechnol. 2011, 7, 632-639. [CrossRef]

242. Doktorovova, S.; Souto, E.B.; Silva, A.M. Nanotoxicology applied to solid lipid nanoparticles and nanostructured lipid carriers-A systematic review of in vitro data. Eur. J. Pharm. Biopharm. 2014, 87, 1-18. [CrossRef]

243. Shah, R.M.; Malherbe, F.; Eldridge, D.; Palombo, E.A.; Harding, I.H. Physicochemical characterization of solid lipid nanoparticles (SLNs) prepared by a novel microemulsion technique. J. Colloid Interface Sci. 2014, 428, 286-294. [CrossRef]

244. Iqbal, M.A.; Md, S.; Sahni, J.K.; Baboota, S.; Dang, S.; Ali, J. Nanostructured lipid carriers system: Recent advances in drug delivery. J. Drug Target. 2012, 20, 813-830. [CrossRef] [PubMed]

245. Wong, H.L.; Bendayan, R.; Rauth, A.M.; Li, Y.; Wu, X.Y. Chemotherapy with anticancer drugs encapsulated in solid lipid nanoparticles. Adv. Drug Deliv. Rev. 2007, 59, 491-504. [CrossRef] [PubMed]

246. Heurtault, B.; Saulnier, P.; Pech, B.; Proust, J.E.; Benoit, J.P. A novel phase inversion-based process for the preparation of lipid nanocarriers. Pharm. Res. 2002, 19, 875-880. [CrossRef] [PubMed]

247. Heurtault, B.; Saulnier, P.; Pech, B.; Benoit, J.P.; Proust, J.E. Interfacial stability of lipid nanocapsules. Colloid Surf. B 2003, 30, 225-235. [CrossRef]

248. Hirsjarvi, S.; Bastiat, G.; Saulnier, P.; Benoit, J.P. Evaluation of surface deformability of lipid nanocapsules by drop tensiometer technique, and its experimental assessment by dialysis and tangential flow filtration. Int. J. Pharm. 2012, 434, 460-467. [CrossRef]

249. Groo, A.C.; Bossiere, M.; Trichard, L.; Legras, P.; Benoit, J.P.; Lagarce, F. In vivo evaluation of paclitaxel-loaded lipid nanocapsules after intravenous and oral administration on resistant tumor. Nanomedicine 2015, 10, 589-601. [CrossRef]

250. Nguyen, H.T.P.; Munnier, E.; Perse, X.; Vial, F.; Yvergnaux, F.; Perrier, T.; Souce, M.; Chourpa, I. Qualitative and Quantitative Study of the Potential of Lipid Nanocapsules of One Hundred Twenty Nanometers for the Topical Administration of Hydrophobic Molecules. J. Pharm. Sci. 2016, 105, 3191-3198. [CrossRef]

251. Bapat, P.; Ghadi, R.; Chaudhari, D.; Katiyar, S.S.; Jain, S. Tocophersolan stabilized lipid nanocapsules with high drug loading to improve the permeability and oral bioavailability of curcumin. Int. J. Pharm. 2019, 560, 219-227. [CrossRef]

252. Eissa, M.M.; El-Moslemany, R.M.; Ramadan, A.A.; Amer, E.I.; El-Azzouni, M.Z.; El-Khordagui, L.K. Miltefosine Lipid Nanocapsules for Single Dose Oral Treatment of Schistosomiasis Mansoni: A Preclinical Study. PLoS ONE 2015, 10, e0141788. [CrossRef] [PubMed] 
253. Courchesne, W.E. Characterization of a novel, broad-based fungicidal activity for the antiarrhythmic drug amiodarone. J. Pharmacol. Exp. Ther. 2002, 300, 195-199. [CrossRef] [PubMed]

254. Kozubowski, L.; Aboobakar, E.F.; Cardenas, M.E.; Heitman, J. Calcineurin colocalizes with P-bodies and stress granules during thermal stress in Cryptococcus neoformans. Eukaryot Cell 2011, 10, 1396-1402. [CrossRef]

255. Cruz, M.C.; Fox, D.S.; Heitman, J. Calcineurin is required for hyphal elongation during mating and haploid fruiting in Cryptococcus neoformans. EMBO J. 2001, 20, 1020-1032. [CrossRef] [PubMed]

256. Gamarra, S.; Rocha, E.M.F.; Zhang, Y.Q.; Park, S.; Rao, R.; Perlin, D.S. Mechanism of the Synergistic Effect of Amiodarone and Fluconazole in Candida albicans. Antimicrob. Agents Chemother. 2010, 54, 1753-1761. [CrossRef] [PubMed] 